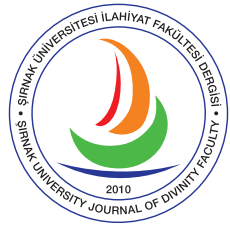

\title{
İslam Hukuk Metodolojisinde Nasların Mubahlığa Delalet Etme Yolları
} The Ways of Expression/Indication of Religious Texts (Nass) to Mubah (Legal Freedom) in Theory of Islamic Provisions

\section{İbrahim Yilmaz}

Doç. Dr., Nevşehir Hacı Bektaş Veli Üniversitesi, İlahiyat Fakültesi, İslam Hukuku Anabilim Dalı Associate Professor, Nevşehir Hacı Bektaș Veli University, Faculty of Divinity, Department of Islamic Law

Nevşehir, Turkey ibrh.yilmaz@hotmail.com https://orcid.org/0000-0001-8912-7769

\section{Makale Bilgisi / Article Information}

Makale Türü / Article Types: Araştırma Makalesi / Research Article

Geliş Tarihi / Received: 11 Mart / March 2019

Kabul Tarihi / Accepted: 08 Nisan / April 2019

Yayın Tarihi / Published: 15 Haziran / June 2019

Cilt / Volume: 10 Sayı / Issue: 22 Sayfa / Pages: 79-108

Atıf / Cite as: Yılmaz, İbrahim. "İslam Hukuk Metodolojisinde Nasların Mubahlığa Delalet Etme Yolları [The Ways of Expression/Indication of Religious Texts (Nass) to Mubah (Legal Freedom) in Theory of Islamic Provisions]". Şırnak Üniversitesi İlahiyat Fakültesi Dergisi - Şırnak University Journal of Divinity Faculty 10/22 (June 2019): 79-108.

https://doi.org/10.35415/sirnakifd.538443

Copyright (C Published by Şırnak Üniversitesi, İlahiyat Fakültesi / Şırnak, Türkiye (Şırnak University, Faculty of Divinity, Şırnak, 73000 Turkey). All rights reserved. 


\title{
Öz
}

İslâm hukuk metodolojisinde (veya İslam hüküm teorisinde) şer’̂̀/teklîfî hükümler; cumhura göre vacip, mendub, mubah, mekruh ve haram olmak üzere temelde beşe ayrılmaktadır. Bunlardan "mubah", mükellefin yapma ve terk etme arasında muhayyer olduğu hukuki serbest alanları ifade etmekte olup şer'î hükümler içerisinde en geniş alanı oluşturmaktadır. Diğer taraftan İslam hukukunda haramlar/yasaklar sınırlıdır ve bunlar naslarla belirlenmiștir. Prensip olarak haramların dışında kalan durumlar, helal (hukuken serbest olan) alanı oluşturmaktadır. Fıkıh literatüründe helal bazen mubah ile eş anlamlı olarak kullanılmakla birlikte mutlak olarak zikredildiğinde mendup ve vacibi de içerisine almaktadır. Bu yüzden ibaha/mubahlık (hukuki serbestlik) ifade eden üslupların/yolların ayrıca tespit edilmesi önem arz etmektedir. Mubahlığa delalet eden "ibaha" lafzı veya bu kelimenin türevleri Kuran'da geçmemekle birlikte bazı hadis metinlerinde "ibaha" lafzı geçmektedir. Diğer taraftan İslam hukukunda, aksine bir delil veya karine olmadığı sürece kesin yükümlülük bildiren taleplerin (emir ve nehiy) dışında kalan fiillerde mubahlığın esas olduğu temel bir ilke olarak kabul edilmiştir. Nitekim bu çerçevede Kuran ve Sünnet lafızlarında, doğrudan (sarahaten) veya dolaylı olarak (karine ile) ibahaya delalet eden birçok ifade tarzı/üslup bulunmaktadır. Klasik dönem fikıh usulü eserlerinde ibahayı/mubahlığı bilme yolları üzerinde ayrıca durulmamıştır. Son dönem İslam hukukçuları ise ibahayı/mubahlığı bilme yollarını; "turuku mảrifeti'l-ibâha", "esâlîbü'l-ibâha" ve "sıyağu'l-ibâha" gibi başlıklar altında incelemişlerdir. Ancak bu çalışmalarda mubahlığı bilme yolları bir bütün olarak derli toplu bir şekilde incelenmemiştir. İslam hüküm teorisinde mubahlığı bilme yolları, "nass" ve "nass dışı" olmak üzere temelde ikiye ayrılmaktadır. Nassın mubahlığa delaleti ise doğrudan (sarahaten) ve dolaylı (karine ile) olmak üzere iki şekilde olmaktadır. Prensip olarak naslarla şer'î ibaha olarak isimlendirilen mubah hükümler sabit olmaktadır. Bu makalede, İslam hüküm teorisinde "nasların mubahlığa delalet etme yolları" üzerinde durulacaktır.

Anahtar kelimeler: İslam Hukuku, Hüküm Teorisi, Nass, Delalet, Mubahlık

\begin{abstract}
Shariah provisions in Islamic law methodology (or in theory of Islamic provision); it is basically divided into five: vacip, mendub, mubah, mekruh and haram. Mubah expresses the legally free areas where man is free to do or not. Among the Sharia provisions, the most broad scope is the provisions that are categorized as "mubah". As a matter of fact, prohibitions (harams) in Islamic law are limited and they are determined by religious texts (nass). In principle, the conditions outside the prohibitions (harams) constitute the halal (legally free) area. In fiqh literature, halal is sometimes used as a synonym for mubah, but when it is mentioned as absolute, it includes mendup and vacib. Therefore, it is important to identify the styles / ways expressing ibaha (legal freedom) separately. The word "ibaha", which denotes legal freedom, or the derivatives of this word are not available in the Qur'an, but the word "ibaha" is available in the some texts of Hadiths. On the other hand, in theory of Islamic provisions it was accepted as a fundamental principle that ibaha (legal freedom) was essential in cases outside of the provisions stating the absolute obligation and prohibition. As a matter of fact, there are many expressions / styles in Quran and Sunnah texts, which express legal freedom directly or indirectly. Ways of knowing the legal freedom in the works of classical jurisprudence have not been emphasized. Islamic jurists of the last period have examined the ways to know the legal freedom under the titles of "turuku ma'rifeti'l-ibahha", "esâlîbü'l-ibâha" ve "sîyağu'l-ibâha". However, in these studies, the ways of knowing ibaha/ mubah have not been examined as a whole. The ways of knowing the ibaha (legal freedom) in theory of Islamic provisions are basically divided into religious texts and non-religious means. The signification of religious texts to ibaha (legal freedom) is in two ways: direct and indirect. In principle, mubah provisions, which are called as shariah ibaha, are fixed by religious texts. In this article, the ways of expression/indication of religious texts (nass) to mubah (legal freedom) in theory of islamic provisions will be focused on.
\end{abstract}

Keywords: Islamic Law, Provision Theory, Nass (Religious Text), Expression/Indication, Ibaha/ Legal Freedom 


\section{GİRIŞ}

Fıkıh usulünün temel konularından biri de şer’̂̂ hükümlerdir. Fakîhin/müctehidin temel amacı da tafsîlî delillerden şer’î hükümleri çıkarmaktır. ${ }^{1}$ İslam hüküm teorisinde (şer'̂̀) hükmün, biri kaynağını diğeri muhatabını esas alan iki farklı tanımı yapılmıştır. Tanımda kaynağını esas alan mütekellimîn/Şâfiî usulcülere göre hüküm, Allah’in, iktizâ/taleb veya tahyîr ya da vaz' yönüyle mükelleflerin fiillerine ilişkin hitabıdır. ${ }^{2}$ Tanımda muhatabı (mükellefin fiilini) esas alan fukahaya/Hanefilere göre ise hüküm, Allah’n, iktizâ/taleb veya tahyîr ya da vaz' yönüyle mükelleflerin fiillerine ilişkin hitâbının sonucudur. ${ }^{3}$

Usulcülerin çoğunluğuna göre hüküm, "teklîfî" ve "vaz'î" olmak üzere iki kısma ayrılmaktadır ve mubah teklîfî hükmün kısımlarından sayılmaktadır. ${ }^{5}$ Seyfeddin el-Âmidî (ö. 631/1233) gibi bazı usulcüler ise hükmü; "teklîf̂́”, "vaz î̀" ve "tahyîrî" olmak üzere üç kısma ayırarak mubahın teklîfî hükümlerden ayrı bir konum olduğuna dikkat çekmişlerdir. ${ }^{6}$ Usulcülerin istılahında -mutlak olarak zikredildiğinde- şer’̂̀ hüküm ile kastedilen ise teklîfî hükümlerdir.

1 Ebû Hâmid Muhammed el-Gazzâlî, el-Müstasfâ min ilmi'l-usûl, thk. Hamza b. Züheyr Hafız, (Medine: ty.), 1: 19; Muhammed b. Ali b. Muhammed Şevkânî, İrşâdü’-fühûl ilâ tahkîki ilmi’l-usûl, thk. Ebu Mus'ab Muhammed Saîd el-Bedrî, (Beyrût: 1992), 21-22; Fahrettin Atar, Fıkıh Usûlü, (İstanbul: MÜİF Yayınları, 1996), 4.

2 Bk. Gazzâlî, el-Müstasfâ, 1: 177; Fahreddin er-Râzî, el-Mahsûl fi ilmi'l-usûl, thk. Cabir Feyyyâd el-Alvânî, (Müessesetü'r-Risâle, ty.), 1: 89; Ebu'l-Hasan Ali b. Muhammd Seyfeddin Âmidî, el-İhkâm fî usûli'l-ahkâm, tlk. Abdurrazzak Afifi, (Riyad: Dâru's-Samîî, 2003), 1: 131; Şevkânî, İşâdü’l-fühûl, s. 23; Ahmed Husarî, Nazariyyetü'l-hükm ve mesâdirü't-teșrî fî usûli'l-fikhi'l-İslamî, (Beyrut: Dârü'l-Kitâbi'l-Arabî, 1986), 30.

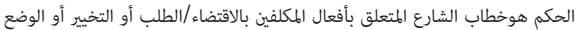

3 Bk. Sa’duddin Mes'ûd b. Ömer et-Taftazânî, Șerhu't-Telvîh ala't-Tavdîh li metni't-Tenkîh fî usuli'l-fikh, Beyrut: Dâru'l-kütübi'l-ilmiyye, ty.), 1: 22-23; Molla Hüsrev, Mirâtü'l-usûl, (İstanbul: Dersaâdet, 1321), 276.

الحكم هوأثرخطاب الشارع المتعلق بأفعال المكلفين بالاقتضاء/الطلب أو التخيير أو الوضع

4 Vazî̀ hüküm, teklîfî hükümlerin varlığı veya yokluğu için alamet olarak konulan sebep, şart, illet, rükûn ve mâni' gibi hükümlerdir. Bk. Şevkânî, İsșâdül-fühûl, 23; Atar, Fikıh Usulü, 133.

5 Şer’̂̀/teklîfî hükmün taksimi ile ilgili örnek olarak bk. Taftazânî, Şerhu't-Telvîh, 1: 24; Nâsıruddin Ebû Saîd Abdullah b. Ömer el-Beyzâvî, Minhâcü’l-vusûl ilâ ilmi'l-usûl, (Dımeşk/Beyrut: Müessesetü’r-risale, ty.), 18; Ebû Abdillah Bedruddin Muhammed b. Bahadır eş-Şâfiî ez-Zerkeşî, el-Bahru’l-muhît fî̀ usûli’l-fikh, nşr. Abdulkadir Abdullah el-Ânî-Ömer Süleymna el-Aşkar, (Kuveyt: Vizârtü'l-evkâfi'ş-şuûniyye, 1992), 1: 127; Abdülvahhab el-Hallâf, İlmü usûli'l-fikh, (İstanbul: el-Mektebetü'l-İslamiyye, 1984), 113-114; Husarî, Nazariyyetü'l-hükm, 33; Atar, Fikıh Usûlü, 116.

6 Bk. Âmidî, el-İhkâm, I, 132-133. Ayrıca bk. Zerkeşî, el-Bahru'l-muhît, 1: 117. 
Usulcülerin teklîfî hüküm için yaptıkları tanım, -vazî̀ (الوضـ) kaydı dışındaşer’î hükmün kaynağını veya muhatabını esas alarak yaptıkları tanımın aynısıdır.? Son dönem İslam hukukçuları ise genellikle mütekellimîn usulcülerin hüküm tanımını esas alarak teklîfî hükmü, "Şâriin mükelleften bir işi yapmasını veya yapmamasını istemesi (el-iktizâ/et-taleb) ya da onu bir işi yapıp yapmama arasında muhayyer bırakması (tahyîr)" "ş şlinde tanımlamışlardır. Teklîfî hükmün kısımlarını/çeşitlerini, tanımda yer alan "iktizâ/talep" ve "tahyîr" kavramlarının içerdikleri anlamlar şekillendirmiş ve usulcüler teklîfî hükmün kısımlarını genel olarak "aksâmü'l-hükmi't-tekliffì" başlığı altında incelemişlerdir.

Teklîfî hükmün tanımında geçen “iktizâ/taleb” kavramı, bir şeyin yapılmasını veya yapılmamasını istemek anlamına gelmektedir. Yapılması istenilen fiiller; farz/ vâcip veya mendup olarak, yapılmaması istenilen filler ise haram veya mekruh olarak isimlendirilmiştir. "Tahyîr" ise bir işin yapılması veya yapılmaması hususunda mükellefi muhayyer/serbest bırakmaktır. Mükellefin eşit seviyede muhayyer bırakıldığ fiillere ise mubah denilmektedir. ${ }^{10}$

Bir fıkıh usulü terimi olarak ise mubah kavramının birçok tanımı yapılmıştır. ${ }^{11}$ Ancak bu tanımlar; "herhangi bir zemm (kınama) ve medh (övgü) olmaksızın Şâri'in mükellefi yapıp yapmamakta muhayyer bıraktığ fiil" 12 anlamında birleşmektedir. Buna göre şerî bir hüküm olarak mubah, "Şâri'in, yapma ve terk etme arasinda mükellefi muhayyer biraktığ veya yapana medh (övgü) ve zemmin (kınama) taalluk etmediği şey"13 anlamına gelmektedir.

Diğer taraftan mahiyeti/yapısı itibariyle mubah, Şâri'in hitabı ile sabit olup olmaması yönüyle "şer̂î ibaha" ve "aslî ibaha" olmak üzere temelde ikiye ayrılmaktadır. Şer'î ibaha, doğrudan veya dolaylı (karine) olarak Şâri’in hitabı (nass) ile sabit olan ibaha şeklidir. ${ }^{14}$ Şer'î ibaha, ya ilk baştan Şâri'in hitabı ile bir fiilin mubah olması şeklinde veya daha sonra nesh veya ruhsat yoluyla bir fiilin mubah olması

7 Teklifi hükmün tanımı ile ilgili bk. Zekiyyüddin Şaban, İslam Hukuk İlminin Esasları (Usûlü’l-fikıh), trc. İbrahim Kâfi Dönmez, (Ankara: Türkiye Diyanet Vakfı Yayınları, 2015), 227, 230; Davut İltaş, "Hüküm Teorisi”, İslam Hukukuna Giriş, Edt. Apaydın, H. Yunus, (Eskişehir: Anadolu Üni. Yayınları, 2013), 101-102.

8 Bk. Hallâf, İlmü usûli'l-fikh, 114; Muhammed Ebû Zehre, Usûlüll-fikh, (İstanbul: Tebliğ Yayınları, ty.), 27; Şaban, Usûlü'l-fikh, 227, 230; Abdülkerim ez-Zeydan, el-Vecîz fî usûli'l-fikh, (Beyrut: Müessesetü’r-Risâle, 2011), 25; Atar, Fikıh Usûlü, 117; Muhammed Ebü’l-Feth el-Beyânûnî, "Hüküm”, Türkiye Diyanet Vakfı İslam Ansiklopedisi, (Ankara: TDV Yayınları, 1998), 18: 467.

9 Bk. Hallâf, İlmü usûli'l-fikh, 113-114; Zeydan, el-Vecîz, 25; Husarî, Nazariyyetül-hükm, 33.

10 Bk. Gazzâlî, el-Müstasfâ, 1: 210-211; Râzî, el-Mahsûl, 1: 89; Âmidî, el-İhkâm, 1: 132-133; Zerkeşî, el-Bahru'lmuhît, 1: 173; Zeydan, el-Vecîz, 23; Atar, Fikıh Usûlü, 116.

11 Usulcülerin mubahın farklı tanımları için bk. Medkûr, Nazariyyetü'l-ibâha, 44-49; el-Mevsûatül-fikhiyye, "İbâha", (Kuveyt: Vizâratü'l-evkâf veş-şuûni'l-İslamiyye el-Kuveyt, 1983), 1: 156-157.

12 Bk. Hallâf, İlmü usûli'l-fikh, 130; Zeydan, el-Vecîz, 38; Şaban, Usûlül-fikh, 253.

13 Medkûr, Nazariyyetü'l-ibâha, 32; Husarî, Nazariyyetü’l-hükm, 69; Vehbe Zühaylî, Usulü'l-fikhi'l-İslamî, (D1meşk: Dâru'l-fikr, 1986), 1: 45, 87.

14 Muhammed Seyyid Bey, Fıkıh Usulü (Giriş), Yay. Haz. Hasan Karayiğit, İstanbul: Düşün Yay., 2010), 73; el-Mevsûatü’l-fikhiyye, "İbâha”, 1: 132; İ. Kâfi Dönmez, "Mubah”, Türkiye Diyanet Vakfı İslam Ansiklopedisi, (Ankara: TDV Yayınları, 2005), 30: 342. 
şeklinde olabilir. Buna göre Şâri'in hitabı ile "yapma" ve "yapmama" arasında muhayyerlik bildiren tüm mubahlar bu kısma girmektedir. ${ }^{15}$ İbaha-i aklîyye olarak da isimlendirilen ${ }^{16}$ aslî ibaha ise Şâri'in sükût ettiği (meskûtün anh), itibar ve ilga ettiği ile ilgili herhangi bir nassın bulunmadığı durumları ifade etmek için kullanılan bir ibaha çeşididir. ${ }^{17}$ Usulcülere göre aslî ibaha da şer î ibaha hükmündedir. ${ }^{18}$

İslam hukukunda haramlar/yasaklar sınırlıdır ve bunların neler olduğu naslar tarafından belirtilmiştir. ${ }^{19}$ Prensip olarak haramların/yasakların dışında kalan durumlar helal alanı oluşturmaktadır. Fıkıh literatüründe bazen helal ile mubah eş anlamlı olarak kullanılmakla birlikte helal kavramı içerisine mubah, mendup ve vacibi de aldığı için mubah kavramından daha geniştir. ${ }^{20}$ Bu yüzden mubahlık ifade eden üslupların ayrıca tespit edilmesi önem arz etmektedir.

Mubahlığa delalet eden "ibaha" lafzı veya bu kelimenin türevleri Kuran'da geçmemekle birlikte bazı hadis metinlerinde "ibaha" lafzının geçtiği görülmektedir. ${ }^{21}$ Örneğin Hz. Peygamber (as) bir hadislerinde; "Beyti tavaf etmek namazdır. Ancak Allah tavafta konuşmayı mubah kılmıştır (أباح فية المنطق" (ا) " Kim tavaf esnasında konuşursa hayırdan başka bir şey konuşmasın"22 buyurmuştur. Ancak, hadisin bu şekildeki isnadının zayıf olduğu söylenmektedir. ${ }^{23}$ Hadisin sahih olan farklı rivayetlerinde ve tahriclerinde ise "أبــل " fiilinin yerine geçmektedir.

15 el-Mevsûatül-fikhiyye, "İbâha", 1: 132.

16 Ebû Ayyâş Muhammed Abdül'alî b. Nizamüddin Bahrululûm el-Leknevî el-Ensârî, Fevâtihu'r-rahamût bi şerhi Müsellemi's-sübût, tsh. Abdullah Mahmud Muhammed Ömer, Beyrut: Dârul'l-kütübi'l-ilmiyye, 2002) 1: 42; Muhammed b. Afîfi el-Bâcûrî Hudarî (Bek/Bey), Usûlü'l-fikh, (Misır: el-Mektebetü’t-Ticâriyyetü'l-Kübra, 1969), 352-353; M. Sellâm Medkûr, Nazariyyetü'l-ibâha inde'l-usuliyyin ve'l-fukâhâ, (Kahire: Dâru’n-Nehdati'l-Arabiyye, 1984), 496.

17 Hudarî, Usûl, 352-353; Seyyid Bey, Fıkıh Usûlü, 73; el-Mevsûatül-fikhiyye, "İbâha", 1: 132.

18 Bk. Râzî, el-Mahsûl, 2: 213-214; Bihârî, Muhibbüllah b. Abdüşşekûr, Müsellemü’s-sübût, (Fevâtihu'r-rahamût bi şerhi Müsellemi's-sübût ile birlikte) tsh. Abdullah Mahmud Muhammed Ömer, Dârul'l-kütübi'l-ilmiyye, Beyrut 2002, 1: 91.

19 Örnek olarak bk. el-Bakara, 2/173; en-Nahl, 16/115

"Allah, size ancak leş, kan, domuz eti ve Allah’tan başkası adına kesileni haram kıldı. Ama kim mecbur olur da, istismar etmeksizin ve zaruret ölçüsünü aşmaksızın yemek zorunda kalırsa, ona günah yoktur. Şüphesiz, Allah çok bağışlayandır, çok merhamet edendir.” (Bakara, 2/173)

20 Medkûr, Nazariyyetüll-ibâha, 85-86; el-Mevsûatü'l-fikhiyye, "İbâha”, 1: 127; el-Mevsûatü'l-fikhiyye, "Helal", (Kuveyt: Vizâratü’l-evkâf ve’ş-şuûni'l-İslamiyye el-Kuveyt, 1990), 18: 74; Dönmez, "Mubah”, 30:342; Ferhat Koca, "Helal”, Türkiye Diyanet Vakfi İslam Ansiklopedisi, (Ankara: TDV Yayınları, 1998), 17: 176-177.

21 Bk. Wensinck, Arent Jean, el-Mu'cemü'l-müfehres li-elfâzi'l-hadîsin-nebevî (Concordance et indices de la tradition musulmane), I-VIII, İstanbul 1986, "bvh” md. Ayrıca bk. Uğur Bekir Dilek, İslam Hukuk Metodolojisinde Teklifi Hüküm Terimleri: Doğuşu-Gelişimi-Terimleşmesi, Doktora Tezi, (Konya: Selçuk Üniversitesi, 2010), 174-175: Uğur Bekir Dilek, “Teklîfî hüküm İfade Eden Kavramların Doğuşu, Gelişimi ve Terimleşmesi”, İslam Hukuku Araşto-ırmaları Dergisi, sayı: 18 (2011): 239; Recep Çetintaş, İlk Beş Asır Fıııh Usulü Literatüründe Teklifi Hüküm Terminolojisi, Doktora Tezi, (İstanbul: Marmara Üniversitesi, 2014), 243-244.

22 Dârimî, Sünen, (İstanbul: Çağrı Yayınları, 1992), 1: 374 (Kitâbü'l-menâsik/el-Hacc, 32, Babü'l-kelâm fi't-tavâf,

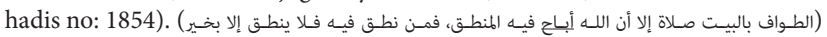

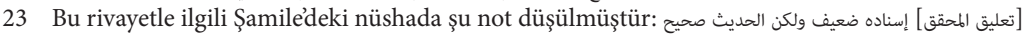

24 Örnek olarak bk. Ebû Cafer Ahmed b. Muhammed et-Tahâvî, Şerhu müşkilil-âsâr, thk. Şuayb el-Arnavût, (1-16), (Beyrut: müessesetü’r-risâle, 1994/1915h.), 14:200; Ebû Cafer Ahmed b. Muhammed et-Tahâvî, Şerhu meâni'l-âsâr, thk. Muhammed Zührî en-Neccâr-Muhammed Sayd Câdu'l-Hakk, (1-5), (Misır: Alemü'l-kütüb, 1984), 2:178; Ebû Abdillah el-Hakim en-Nisâbûrî, el-Müstedrek ale's-sahîhayn, thk. Mustafa Abdülkadir 
Diğer taraftan İslam hukukunda, aksine bir delil veya karine olmadığı sürece kesin yükümlülük bildiren taleplerin (emir ve nehiy) dışında kalan fiillerde mubahlığın esas olduğu temel bir ilke olarak kabul edilmiştir. Nitekim Kuran ve Sünnet lafızlarında, doğrudan (sarahaten) veya dolaylı olarak (karine ile) ibahaya delalet eden birçok ifade tarzı/üslup bulunmaktadır. ${ }^{25}$

Klasik dönem fikıh usulü eserlerinde kesin hüküm ifade eden $\operatorname{emir}^{26}$ ve nehiy ${ }^{27}$ sîğalarının hükme delaleti üzerinde detaylı olarak durulmuş, emir ve nehiy sîğalarının hangi durumlarda vücûp veya hürmete delalet ettiği, hangi durumlarda vücûp veya hürmetin dışında başka bir hükme delalet ettiği tespit edilmeye çalışılmıştır. ${ }^{28}$ Buna mukabil klasik dönem fikıh usulü eserlerinde mubahla ilgili birçok konu $^{29}$ üzerinde durulmakla birlikte mubahlığı bildiren yollar/üsluplar üzerinde ayrıca durulmamıştır. Son dönem İslam hukukçuları ise ibahayı/mubahlığı bilme yollarını "turuku márifeti'l-ibaha"30; "esâlîbü’l-ibâha"31 ve "sıyağu'l-ibâha"32 gibi başlıklar altında işlemişlerdir.

Mubahlığı bilme yolları, "nass" ve "nass dışı" olmak üzere temelde ikiye ayrılmaktadır. Nassın mubahlığa delaleti ise doğrudan (sarahaten) ve dolaylı (karine ile) olmak üzere iki şekilde olmaktadır. ${ }^{33}$ Nass dışı mubahlığı bilme yolları

Ata, (1-4), (Beyrut: Daru'l-kütübi'l-ilmiyye, 1990), 1: 663; Ebû Muhammed Abdullah b. Ali b. el-Cârûd enNîsâbûrî (İbnü'l-Cârûd), el-Müntekâ fi's-süneni'l-müsnedeti, -Babü'l-menâsik-, thk. Abdullah Ömer el-Bârûdî, (Beyrut: Müessesetü'l-kitâbi’s-sikâfiyye, 1988), 1: 120).

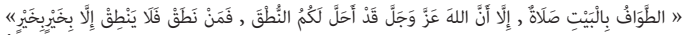

25 İ̉âha'ya delalet eden üsluplar ile ilgili geniş bilgi için bo Medkûr, Nazariyyetü'l-ibâha, 65-80; M. Sellâm Medkûr, Mebâhisü'l-hükm inde’l-usûliyyîn, (Kahire: Dâru'n-nehdati'l-arabiyye, 1959), 111-112; el-Mevsûatü'l-fik-

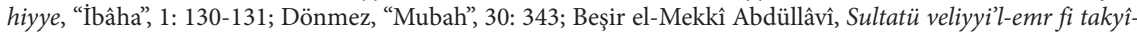
di'l-mubâh, (Beyrut: Dâru Mektebeti'l-Maârif, 2011), 61-74.

26 Emir siğasının hükme delaleti hakkında bk. Râfi' b. Taha er-Rufâî, el-Emr inde’l-usûliyyîn, (Dımeşk/Beyrut: Daru Mehabbe/Daru Âye, 2006); Âdil Attâfî, el-Emru inde'l-usûliyyîn beyne's-sîğati ve’l-ma'nâ, (Master Tezi, Câmiatü Muhammed Haydar, Külliyetü'l-âdâb ve'l-lüğât, Baskara 2012/2013); Salim Öğüt, "Emir (F1kıh)”, Türkiye Diyanet Vakfi İslam Ansiklopedisi, (Ankara: TDV Yayınları, 1995), 11: 119-121.

27 Nehiy siğasının hükme delaleti hakkında bk. Ziyad İbrahim Hüseyin Mikdâd Delâletü sîğati’n-nehyi ale’l-ahkâmişşser'iyye, (Mastır Tezi, Câmiatü’n-necâhi'l-vatâniyye, Külliyetü’ş-şerîa, 1993); H. Yunus Apaydın, "Nehiy (Fıkıh)", Türkiye Diyanet Vakfı İslam Ansiklopedisi, (Ankara: TDV Yayınları, 2006), 32: 544-547.

28 Emir ve nehiy kipinin hükme delaleti hakkında bk. Ebî Zeyd Ubeydullah b. Umer b. Îsâ ed-Debûsî Takvîmü'l-edille fî usûli'l-fikh, thk. Şeyh Halil Muhyiddin el-Meys, (Beyrut: Dâru'l-kütübi'l-ilmiyye, 2007), 407414, Ayrıca bk. 36-60; Ebû Bekr, Muhammed b. Ebî Sehl Serahsî, Usûlü'l-s-Serahsî, thk. Ebu'l-vefa el-Afğanî, (Beyrut: Dâru'l-Ktübi'l-ilmiyye, 1993), 1: 11-100. Emir ve nehiy siğalarının hükme delaleti hakkında geniş bilgi için ayrıca bk. Mustafa Ca’ferî, el-Emru ve’n-Nehyü ınde’l-usûliyyîn, (Hartum: Câmiatü Hartûm, Külliyetü’l-kânûn, 2009.); Pala, Ali İhsan, İslam Hukuk Metodolojisinde Emir ve Yasakların Yorumu, (Ankara: Fecr Yayınları, 2009).

29 Klasik dönem fikıh usulü kitaplarında mubah ile ilgili "mubahın teklîfî hüküm olup olmaması", “mubahın şer' hüküm olup olmaması", "mubahın emredilmiş olup olmaması", "mubahın talep içerip içermemesi” gibi birçok konu üzerinde durulmuştur. (Bk. Gazzâlî, el-Müstasfâ, 1: 243-247; Âmidî, el-İhkâm, 1: 166-169; Zerkeşî, elBahru'l-muhît, 1: 277-283.)

30 Bk. el-Mevsûatü’l-fikhiyye, “İbâha”, 1: 130-131.

31 Medkûr, Nazariyyetü'l-ibâha, 65-80.

32 Abdüllâvî, Sultatü veliyyi'l-emr, 61-74.

33 Medkûr, Nazariyyetüll-ibâha, 66-73; el-Mevsûatü'l-fikhiyye, “İbâha”, 1: 129. 
ise prensip olarak Şâri’nin sessiz kaldığı durumların mubahlığa delalet etmesidir. ${ }^{34}$ Prensip olarak naslarla şer’̂̀ ibaha ile ilgili hükümler; nass dışı yollarla aslî ibaha ile ilgili hükümler sabit olmaktadır.

Aşağıda, kısaca İslam hüküm teorisinde "nassın mubahlığa delalet etme yolları" üzerinde durulacaktır. ${ }^{35}$ Ancak burada hemen belirtelim ki bir nassin (ayet veya hadisin) içermiş olduğu özel lafızlardan veya ifade etmiş olduğu genel manadan dolayı farklı başlıklar altında değerlendirilmesi mümkündür. Bu gibi durumlarda nassın klasik usul kitaplarında zikredildiği konu başlı̆̆ı altında verilmesi tercih edilmiştir.

\section{NASSIN LAFZIYLA DOĞRUDAN MUBAHLIĞA DELALET ETMESI}

Kuran ve Sünnet'te yer alan birçok ifade, "izin" anlamı içerdiği için karineye ihtiyaç olmaksızın sarih biçimde mubahlığa delâlet etmektedir. Nitekim yapılmasında sıkıntı, sakınca, günah, vebal bulunmadiğın ve sorumluluğun söz konusu olmadığıı bildiren bazı ifadeler; yeryüzündeki her şeyin insanların hizmetine sunulduğunu (teshîr) bildiren ifadeler ve mubahlık bildiren bazı harfler doğrudan mubahlık bildirmektedir. ${ }^{36}$ Aşağıda doğrudan mubahlığa delalet eden üsluplardan bahsedilecektir.

\subsection{Nassin Sarahaten Mubahlığa Delalet Etmesi}

Mubahlığı bilme yollarının başında nassın, yani Kuran ve Sünnet lafızlarının doğrudan mubahllğa delalet etmesi gelmektedir. Burada konuyla ilgili örneklere geçmeden önce fikıh usulünde lafzın hükme delaleti ile şu konuyu göz önünde bulundurmak uygun olacaktır. Bilindiği gibi fikıh usulünde, lafız belirli bir manayı/ hükmü açıklamak üzere sevk edilmişse bu lafza terim olarak "nass" denilmektedir. "Nass" olarak isimlendirilen lafız, sevk edildiği manaya açıç̧a delalet etmektedir. Sevk ediliş amacı olmamakla birlikte kendisi işitilince manası hemen açıcça anlaşılan lafza ise bir fikıh usulü terimi olarak "zâhir" denilmektedir. ${ }^{37}$ Aşağıdaki

34 Bu konu ayrı bir makale konusu olarak incelenecektir.

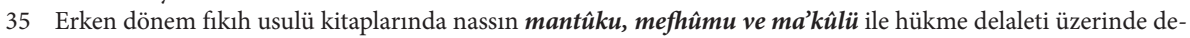
taylı olarak durulmuştur. Nassı bizzat lafzıyla/nazmıla hükme delaleti Hanefi fikıh usulü eserlerinde ; "Emir", "Nehiy” ve "Hükme Delalet Yönünden Lafzın Çeşitleri” gibi başlıklar altında incelenmiştir (Örnek olarak bk. Debûsî, Takvîmül-edille, 36-60; 94-104.) Mütekellimîn fikıh usulü eserlerinde ise "manzûmun (mantûkun) delaleti" ve "mefhûmun delaleti” gibi başlıklar altında incelenmiştir. (Örnek olarak bk. Gazzâlî, el-Müstasfâ, 1: 20, 3: 2-446.) Son dönem usulcüler ise nassın bizzat lafız/nazmı ile hükme delaletini “Turuku istinbâtı'l-ahkâm”, "Lafzî Usul Kaideleri”, "Lafzî Mebhasler/Lafzî İstidlâl Metotları” gibi başlıklar altında incelemektedirler. Örnek olarak bk. Şaban, Zekiyyüddin, İslam Hukuk İlminin Esasları (Usûlü'l-fikıh), trc. İbrahim Kâfi Dönmez, Ankara 2015, 309-412; Atar, Fıkıh Usûlü, 169-238; H. Yunus Apaydın, İslam Hukuk Usulü, (Ankara: Bilay Yaynıcılık, 2017), 207-263. Mütekellimîn yöntemine göre nassın hükme delaleti konusunda geniş bilgi için bk. Davut İltaş, Fıkıh Usulünde Mütekellimîn yönteminin Delâlet Anlayıșı, (İstanbul: İSAM Yayınları, 2011), 127397.

36 Medkûr, Nazariyyetüll-ibâha, 66-73; Dönmez, "Mubâh", 30: 341.

37 Debûsî, Takvîmüll-edille, 116; Şaban, Usûlü'l-fikh, 369, 371; Atar, Fıkıh Usûlü, 209-210. 
örneklerde lafız, fikıh usulündeki terim anlamı ile ya "nass" olarak veya "zahir" olarak doğrudan mubahlığa delalet etmektedir.

1) "Eğer, (velisi olduğunuz) yetim kızlar (ile evlenip onlar) hakkında adaletsizlik etmekten korkarsanız, (onları değil), size helâl olan (başka) kadınlardan ikişer, üçer, dörder olmak üzere nikâhlayın." (el-Nisa, 4/3.)

$\mathrm{Bu}$ ayetin sevk ediliş amacı, yetim kızlara adaletli davranılması ve erkeğin aynı anda birden fazla (en çok dörde kadar) kadınla evlenmesinin mubah olmasıdır. Ayet bu konuda nasstır ve siğasıyla doğrudan İslam hukukunda çok evliliğin mubah olmasina delalet etmektedir. Ancak ayet, zahiriyle evlenmenin mubah olduğuna da delalet etmektedir. ${ }^{38}$

Usulcülerin çoğunluğuna göre mutlak emir kipi vücûb ifade etmektedir. Ancak karinenin olması halinde emir kipi vücûbun dışında nedb veya ibahaya da delalet etmektedir. ${ }^{39}$ Burada da "nikâhlayın/evlenin" hitabı her ne kadar emir kipinde gelmiş olsa da İslam hukukçuları emrin ibahahaya delalet ettiği konusunda ittifak/icma etmişlerdir. ${ }^{40}$

2) "Ey peygamber! Kadınları boşamak istediğinizde, onları iddetlerini dikkate alarak (temizlik hâlinde) boşayın ve iddeti sayın." (et-Talak, 65/1)

Bu ayetin sevk ediliş amacı, boşamanın kadının iddetini gözetttiği temizlik devresinde olmasının vacip olmasıdır. Ayet bu konuda nasstır. Ancak ayet ("tallaktûmü’n-nisâe" lafzı) zahiri ile boşamanın mubah olmasına delalet etmektedir. ${ }^{41}$

3) "Faiz yiyenler, ancak şeytanın çarptığı kimsenin kalktığı gibi kalkarlar. Bu, onların, 'Alışveriş de faiz gibidir' demelerinden dolayıdır. Oysa Allah, alışverişi helâl, faizi haram kılmıştır." (el-Bakara, 2/275)

$\mathrm{Bu}$ ayetin sevk ediliş amacı, alım-satım ile faiz arasındaki farkı belirtmektir. Ayet bu konuda nasstır. Ancak ayet zahiri ile doğrudan faizin haram, alım-satımın ise helal/mubah olduğuna delalet etmektedir. ${ }^{42}$

Yine "Müslümanlar üç şeyde ortaktır: Su, otlak ve ateş"³ anlamındaki hadis, sayılan bu üç şeyin herhangi bir şahsa veya gruba tahsis edilmeksizin tüm Müslümanlar için mubah olduğunu ifade etmektedir. ${ }^{44}$ Ancak bu hadiste ifade edilen "su, otlak ve ateş", kimsenin mülkünde olmayan ovalarda ve dağlarda bulunan

38 Debûsî, Takvîmü'l-edille, 116; Şaban, Usûlü'l-fikh, 369-370, 393-394; Atar, Fıkıh Usulü, 209; Apaydın, İslam Hukuk Usulü, 232.

39 Emir kipinin ibahaya delalet etmesi ile ilgili bk. Emrin (Karine ile) Mubahlığa Delalet Etmesi.

40 Ebû Ceyb, Sa’dî, Mevsûatü'l-icma' fi'l-fikhi'l-İslamî, (Dımeşk: Dâru'l-fikr, 1984), 2: 1087.

41 Debûsî, Takvîmül-edille, 116.

42 Debûsî, Takvîmüll-edille, 116; Şaban, Usûlü'l-fıkh, 369, 371; Atar, Fıkıh Usulü, 209; Apaydın, İslam Hukuk Usulï, 232.

43 Ebû Dâvûd, "Buŷ̂"”, 60 (nr.3477); Ahmed b. Hanbel, Müsned, 5: 364.

44 Medkûr, Nazariyyetü'l-ibâha, 114-115. 
şeyler için geçerlidir. Aksi halde birisinin özel mülkiyetinde bulunan su, otlak ve ateșten istifade onun iznine tabidir. ${ }^{45}$

\subsection{Nassın Günah ve Sıkıntıyı Nefyederek Mubahlığa Delalet Etmesi}

Bir fiilin yapılması veya terk edilmesinden dolayı günahın (ism/cünâh), s1kıntının (harec), sorumluluğun/kınamanın (sebîl), sorgulamanın (muâhaze) olmayacağını ve günahın kaldırıldığını (raf'ü'l-kalem) ifade eden üsluplar sarih olarak mubahlığa delalet eden naslardan kabul edilmektedir. ${ }^{46}$ Nitekim bu ifadeleri içeren naslarda fiilin yapılması veya terk edilmesi istenmeyip mükellef muhayyer bırakılmaktadır. Muhayyerlik ise mubahın mahiyetinde olan bir özelliktir. ${ }^{47}$ Aşağıdaki örneklerde yer alan "ism", "cünâh", "harec", muâhaze", "sebîl”, "ref'u'l-kalem" kavramları ile ilgili "günahın", "sıkıntının”, "sorgulamanın”, "cezanın” kaldırılmas1nın bildirilmesi bahse konu fiillerin mubahllğına delalet etmektedir" ${ }^{48}$;

1) "Sayılı günlerde" Allah’ı anın (telbiye ve tekbir getirin). Kim iki gün içinde acele edip (Mina’dan Mekke’ye) dönerse, ona günah (ism) yoktur. Kim geri kalırsa, ona da günah (ism) yoktur. Bu, Allaha karşı gelmekten sakınanlar içindir. Allaha karşı gelmekten sakının ve onun huzurunda toplanacağınızı bilin." (el-Bakara, 2/203.)

Ayette farz olan tavafı eda ettikten sonra şeytan taşlamak için hacıların Mina'da iki veya üç gün gecelemelerinin hükmünden bahsedilmektedir. Ayette, memleketlerine erken dönmek için Mina’da iki gün geceleyip Mekke’ye dönmekte acele etmekte bir günah olmadığ 1 gibi dönmeyi geciktirenler için de bir günah (ism) olmadığı belirtilmektedir. Buna göre Mina’dan Mekke’ye dönüşü geciktirme hususunda kişi muhayyerdir. Muhayyerlik ise mubahlığı ifade etmektedir. ${ }^{50}$

2) "Köre güçlük (harec) yoktur, topala güçlük yoktur, hastaya da güçlük yoktur. Kendi evlerinizde veya babalarınızın evlerinde veya annelerinizin evlerinde veya erkek kardeşlerinizin evlerinde veya kız kardeşlerinizin evlerinde veya amcalarınızın evlerinde veya halalarınızın evlerinde veya dayılarınızın evlerinde veya teyzelerinizin evlerinde veya anahtarlarına sahip olduğunuz evlerde ya da dostlarınızın evlerinde yemek yemenizde de bir sakınca yoktur." (en-Nur, 24/61)

45 Medkûr, Nazariyyetü'l-ibâha, 116.

46 İbn Hazm, el-İhkâm fî usûli'l-ahkâm, thk. Muhammed Şakir, (Beyrut: Dâru'l-âfâki'l-cedîde, ty.), 2: 36, 37; Hallâf, Ilmü usûli'l-fikıh, 130; Zeydan, el-Vecîz, 38-39; Medkûr, Nazariyyetü'l-ibâha, 66-70; Husarî, Nazariyyetül-hükm, 74 .

47 Bir fiilin işlenmesinde günah ve sıkıntının olmamasının her zaman muhayyerlik anlamı içermediği hakkında bk. Ebû İshak İbrahim b. Mûsâ eş-Şâtıbî, el-Muvâfakât fî̀ usûliş̧ş̧eriâ, nşr./tlk. Abdullah Dıraz, Beyrut:Dâru'l-marife, 1975), 1: 146-147.

48 Konuyla ilgili örnekler için bk. Medkûr, Nazariyyetül-ibâha, 66-72

49 "Sayılı günler"den maksat, teşrik günleri olan Zilhicce ayının, 9,10,11,12 ve 13. günleridir.

50 Muhammed Hamdi Yazır Elmalılı, Hak Dini Kurân Dili, (İstanbul: Eser Neşriyat, 1979), 2: 730-731; Medkûr, Nazariyyetü'l-ibâha, 66 . 
Ayette zikredilen özür sahiplerinin savaşa/cihada katılmamalarında bir sıkıntı ve günah (harec) olmadığ ifade edilmiştir. Bu ise özür sahiplerinin savaşa katılmamalarının mubah olduğunu ifade etmektedir. ${ }^{51}$

3) “...Eğer (anne ve baba) kendi aralarında danışıp anlaşarak (iki yıl dolmadan) çocuğu sütten kesmek isterlerse, onlara günah (cünâh) yoktur. Eğer çocuklarınızı (bir sütanneye) emzirtmek isterseniz, örfe uygun olarak vereceğiniz ücreti güzelce ödediğiniz takdirde size bir günah (cünâh) yoktur. Allah’a karşı gelmekten sakının ve bilin ki Allah, yapmakta olduklarınızı hakkıyla görendir." (el-Bakara, 2/ 233.)

$\mathrm{Bu}$ ayette çocuğun iki yıl dolmadan sütten kesilmesinde veya sütanneye verilmesinde bir günah (cünâh) olmadığı, bu konuda ebeveynin muhayyer olduğu belirtilmektedir. Muhayyerlik ise mubahllğ 1 ifade etmektedir. ${ }^{52}$

4) "(Vefat iddeti beklemekte olan) kadınlara kendileri ile evlenmek istediğinizi üstii kapalı olarak anlatmanızda veya bu isteğinizi içinizde saklamanızda sizin için bir günah (cünâh) yoktur." (el-Bakara, 2/235.)

Prensip olarak maksadı ifade eden sarih ve kinâî her türlü lafız ve işaretlerle evlilik teklifinde bulunmak mubahtır. Ancak ayette "üstü kapalı" kaydı konularak kocası ölen kadınlara iddet içerisinde sarih bir şekilde evlilik teklifinde bulunulmasının caiz olmadığı ifade edilmektedir. Buna göre ayetin lafzından vefat iddeti bekleyen kadına bu dönem içerisinde telmih ve tariz yolu ile üstü kapalı (imalı) bir şekilde evlilik teklifinde bulunulmasında bir günah/sakınca (cünâh) olmadığı anlaşılmaktadır. Bu ise vefat iddeti bekleyen kadına üstü kapalı olarak yapılan evlilik teklifinin mubah olduğunu göstermektedir. ${ }^{53}$

5) "Allah, sizi kasitsız yeminlerinizden dolayı sorumlu tutmaz (muâhaze), fakat sizi kalplerinizin kazandığı (bile bile yaptığınız) yeminlerden sorumlu tutar. Allah, çok bağışlayandır, halîmdir. (Hemen cezalandırmaz, mühlet verir.)" (el-Bakara, 2/225); "Allah, boş bulunarak ettiğiniz yeminlerle sizi sorumlu tutmaz. Ama bile bile yaptı̆̆ınız yeminlerle sizi sorumlu tutar." (el-Maide, 5/89)

$\mathrm{Bu}$ ayetlerde, boş yere yemin etmekten (yemini lağ $\mathrm{v}^{54}$ ) dolayı sorgulamanın

51 Muhammed Tahir b. Âşûr, et-Tahrîr ve’t-tenvîr, (Tunus: Dâru'-Tûnisiyye, 1984), 18: 299-300; Medkûr, Nazariyyetü'l-ibâha, 66 .

52 Ebû Abdillah Muhammed b. Ahmed el-Ensârî el-Kurtubî, el-Câmi li ahkâmi'l-Kurân, thk. Abdullah b. Abdulmuhsin et-Türkî, (Beyrut: Müessesetü’r-risâle, 2006), 4: 109; Medkûr, Nazariyyetü'l-ibâha, 67-68.

53 Kurtubî, el-Câmi', 4: 144-146; Muhammed Ebu Zehra, el-Ahvâlüş-şahsiyye, (Kâhire: Dâru'l-fikri'i-Arabî, 1957), 29; Medkûr, Nazariyyetü'l-ibâha, 68.

54 Lağv, gamûs ve münakid olmak üzere üç türlü yenim vardır. Yemin ve çeşitleri hakkında geniş bilgi için bk. Ertuğrul Boynukalın, "Yemin”, Türkiye Diyanet Vakfı İslam Ansiklopedisi, (Ankara: TDV Yayınları, 2013), 43: 416-420.

1) Gamûs yemini: Bile bile yalan yere yapılan yemindir. Bunun keffareti yoktur. Çünkü bu büyük bir vebaldir, keffaretle temizlenmez. Tövbe ve istiğfar gerekir.

2) Lağv yemin: Yanlışlıkla, boş bulunarak yapılan yemin. Buna bir şey gerekmez.

3) Mün'akid yemin: Kişinin gelecekte bir şeyi yapacağına veya yapmayacağına dair ettiği yemin. Bu yeminin bozulması hâlinde keffaret gerekir. Âyet, bu keffaretin nasıl yerine getirileceğini açıklamaktadır 
(muâhazenin) olmadığı belirtilmektedir. Muâhazenin olmaması ise bu fiilin mubah olduğunu göstermektedir. ${ }^{55}$

6) "Zulme uğradıktan sonra, kendini savunup hakkını alan kimseye (ceza vermek için) bir yol (sebîl) yoktur." (eş-Şûrâ, 42/41)

$\mathrm{Bu}$ ayetin geçtiği Şûrâ suresinin 40-43. ayetlerinde haksızlığa ve zulme uğrayan kişinin isterse haksızlığı yapan zalimi affedebileceğinden bahsedilmektedir. ${ }^{56}$ Yukarıda zikredilen ayette ise zulme uğrayanların haksızlığ 1 yapan zalimi affetmek yerine hakkını aramasından ve suçluya/zalime gereken cezanın verilmesi için yardım istemesinden dolayı aleyhine bir "sebîl” olmadığı belirtilmektedir. Burada "sebîl" ile kastedilen yapılmasından dolayı kişiye herhangi bir sorumluluk ve kınamanın olmamasıdır. Dolayısıyla haksızlığa uğrayan kişinin meşru bir şekilde hakkını araması/alması mubah olmaktadır. ${ }^{57}$

7) 'Üç kişiden kalem kaldırıldı (raf' 'ü'l-kalem); uyanıncaya kadar uykuda olan kişiden, akıllanıncaya kadar deli olan kişiden ve ihtilam oluncaya kadar çocuk$\tan .{ }^{\prime 38}$

İslam hukukunda yükümlülüğün temel şartı akıl ve buluğdür. Dolayısıyla bu iki temel şartı taşımayan mecnun (akılsız) ve çocuklar teklifle yükümlü değillerdir. Usul kitaplarında "el-mahkûmu aleyh/mükellef" bahsinde "avârızu'l-ehliyet" başlığı altında bu konu üzerinde durulmaktadır. ${ }^{59} \mathrm{Bu}$ çerçeveden bakıldığında hadiste zikredilen bu üç kişinin bulundukları hal üzere iken yaptıkları fiillerden sorumlu olmayacakları ve onlara günahın terettüp etmeyeceği bildirilmektedir. Dolayısıyla bu üç kişinin bu hal üzere iken bir fiili yapma ve yapmamalarında günahın ve sorumluluğun olmaması bu fiilin onlar için kısmen mubahlık (nisbî ibaha) içerdiği anlaminagelmektedir. ${ }^{60}$

\subsection{Nassın Bir Şeyin İnsanların Hizmetine Musahhar Kılındığını Birdimesinin (Teshîr) veya İnsanların İyiliği İçin Yaratıldığını Bildirmesinin (İmtinân) Mubahlığa Delalet Etmesi}

"Sehhara" fiilinin mastarı olan "teshîr" sözlükte "emri altına vermek, hizmetine sunmak, musahhar kılmak" gibi anlamlara gelmektedir. ${ }^{61}$ Kuran'da, yerde ve gökte her ne var ise insanların hizmetine ve emrine musahhar kılındığg belirtil-

55 Medkûr, Nazariyyetü’l-ibâha, 69.

56 Bu ayetlerin tefsiri ve içerdikleri hükümler için bk. Kurtubî, el-Câmi', 18: 489-497.

57 Kurtubî, el-Câmi', 18: 492-493; Medkûr, Nazariyyetü'l-ibâha, 69.

58 Ebû Dâvûd, "Hudûd”, 17; İbni Mâce, “Talâk”, 15.

59 İslam hukukunda ehliyet şartları ve ehliyet arızaları hakkında bk. Atar, Fıkıh Usûlü, 141-157.

60 Medkûr, Nazariyyetüll-ibâha, 71. Ayrıca bk. Şâtıbî, el-Muvâfakât, 1: 170; Ebû Zehre, Usûlül-fikh, 49-50; Zühaylî, Usûlü'l-fikhi'l-İslamî, 1: 92-93; Muhammed Ebü'l-Feth el-Beyânûnî, el-Hükmü't-teklîfî fişs-serîati'l-İslamiyye, (Dımaşk: Dârü'l-Kalem, 1988), 253.

61 İbn Manzur, “s-h-r” mad., Lisânü’l-Arab, (Kahire: Dâru'l-meârif, 1984), 3: 1963. 
mektedir. ${ }^{62}$ Bir şeyin insanların hizmetine musahhar kılınması ise ancak ondan faydalanmanın mubah olması ile mümkündür. ${ }^{63}$ "Menne" fiilinden "iftiâl" vezninde mastar olan "imtinân" ise sözlükte iyilikte bulunma, verme gibi anlamlara gelmektedir. ${ }^{64}$ Bir şeyin insanlara iyilik için yaratıldığının belirtilmesi de prensip olarak o şeyin mubahlığına delalet etmektedir. ${ }^{65}$ Teshîr ve imtinân içeren aşağıdaki nasslar doğrudan mubahllğa delalet etmektedir ${ }^{66}$.

1) "Allah, içinde gemilerin, emriyle akıp gitmesi, O’nun lütfunu aramanız ve şükretmeniz için denizi sizin hizmetinize musahhar kılandır/emrinize verendir." (el-Câsiye, 45/12)

2) "Göklerdeki ve yerdeki her şeyi kendi katından (bir nimet olarak) sizin hizmetinize verendir." (el-Câsiye, 45/13)

3) "O, taze et yemeniz ve takınacağınız süs eşyası çıkarmanız için denizi sizin hizmetinize verendir." (en-Nahl, 16/14)

4) Hayvanları da yarattı. Onlarda sizin için bir ssınma ve birçok fayda vardır. Hem de onlardan yersiniz." (en-Nahl, 16/5)

5) "Sizi sıcaktan koruyacak elbiseler ve savaşta sizi koruyacak zırhlar verdi. Böylece Allah, Müslüman olasinız diye üzerinizde olan nimetini tamamliyor." (enNahl, 16/81).

Yukarıdaki ayetlerden genel olarak; deniz ürünlerinin mubah/helal olması (el-Câsiye, 45/12; en-Nahl, 16/14), hakkında yasaklama bulunmayan şeylerde asıl olanın mubahlık (aslî ibaha) olması (el-Câsiye, 45/13), hayvan ürünlerinin mubah olması (en-Nahl, 16/5), sıcaktan ve savaştan korunmak için elbise ve zırh gibi koruyucu tedbirlerin alınmasının mubah olması (en-Nahl, 16/81) anlaşılmaktadır.

\subsection{Nasstaki Muhayyerlik Bildiren Bazı Harflerin Mubahlığa Delalet Etmesi}

Nassta bulunan bazı harfler, o işin aslı vacip olsa da, nassta geçen seçeneklerle ilgili muhayyerlik ifade eder. Örneğin kefaretlerle ilgili ayetlerde bulunan “ev/و" edatı muhayyerlik bildirmektedir. ${ }^{67}$ Ancak buradaki ibaha, vacip olan keffaretin kendisi ile ilgili olmayıp keffaretin edası ile ilgili verilen seçeneklerden birinin ter-

62 Örnek olarak bk. er-Ra’d, 13/2; İbrahim, 14/32, 33; en-Nahl, 16/12, 14; el-Hac, 22/65; el-Ankebut, 29/61; Lokman, 31/20,29; el-Fâtır, 35/13; ez-Zümer, 39/5; ez-Zuhruf, 43/13; el-Casiye, 45/12,13; el-Enbiya, 21/29; es-Sad, 38/18, 36; el-Hac, 22/36.

63 Şâtıbî, el-Muvâfakât, 1: 126; Zeydan, el-Vecîz, 214.

64 İbn Manzur, “m-n-n” mad., Lisânü'l-Arab, 4: 4229.

65 İbn Abdüsselâm, İzzeddin (İzz) Ebu Muhammed es-Sülemî, el-İmâm fî beyâni edilleti’l-ahkâm, (Beyrut: Daru'l-beşâiri'l-İslamiyye, 1987), 86.

66 Konuyla ilgili ayetler için ayrıca bk. Abdülbâkî, M. Fuâd, "sehhara” mad., el-Mu'cemü’l-müfehres li elfâzi'l-Kurâni’l-Kerîm, (İstanbul: el-Mektebetü’l-İslamiyye, 1982), 347-348.

67 Serahsî, Usûl, 2: 213; İbn Hazm, el-İhkâm, 1: 51, 3: 6; Ebu'l-Muzafffer Mansur b. Muhammed es-Sem'ânî, Kavâtıu'l-edille fî usûli'l-fikh, thk. Abdullah Hafız Ahmed el-Hakemî, (Riyâd: Mektebetü't-tevbe, 1998), 1: 58. 
cih edilmesi konusunda mükellefin muhayyer bırakılmasıdır. ${ }^{68}$ Dolayısıyla "muhayyerlik" içermesi açısından muhayyer vacibin mubahlıkla bir ilişkisi bulunmaktadir. ${ }^{69}$

Kuran'da “ev/و" edat1 ile mükellefin muhayyer bırakıldığ birçok örnek bulunmaktadır. Örneğin hac veya umre yapmak üzere ihrama girdikten sonra hastalık, düşmanın engellemesi, savaş sebebiyle yolların kapalı olması gibi sebeplerden birinin bulunmasından dolayı muhsar durumda olan kişi tıraş olup ihramdan çıması için üç seçenekten birini yapmak hususunda muhayyer bırakılmaktadır. Konuyla ilgili ayet şöyledir;

"Haccı da umreyi de Allah için tamamlayın. Eğer (düşman, hastalık ve benzer sebeplerle) engellenmiş olursanız artık size kolay gelen kurbanı gönderin. Bu kurban, yerine varıncaya kadar başlarınızı tıraş etmeyin. İçinizden her kim hastalanır veya başından rahatsız olur (da tıraş olmak zorunda kalır)sa fidye olarak ya oruç tutması, ya sadaka vermesi, ya da kurban kesmesi gerekir." (el-Bakara, 2/196.)

Burada ayette geçen "veya" anlamındaki "ev/و" edatı muhayyerlik ifade etmekte olup mükellef bu üç seçenekten birini yapmakta muhayyerdir. ${ }^{70}$

Yine yemin keffareti ile ilgili ayette geçen "veya" anlamındaki "ev/و" edat1 muhayyerlik ifade etmektedir. Konuyla ilgili ayetteki düzenleme şöyledir:

"Allah, boş bulunarak ettiğiniz yeminlerle sizi sorumlu tutmaz. Ama bile bile yaptığınız yeminlerle sizi sorumlu tutar. Bu durumda yeminin keffareti, ailenize yedirdiğinizin orta hâllisinden on yoksulu doyurmak yahut onları giydirmek ya da bir köle azat etmektir. Kim (bu imkânı) bulamazsa, onun keffareti üç gün oruç tutmaktır. İște yemin ettiğiniz vakit yeminlerinizin keffareti budur. Yeminlerinizi tutun. Allah, size ayetlerini işte böyle açıllyyor ki şükredesiniz." (el-Mâide, 5/89)

$\mathrm{Bu}$ ayette mün'akid yeminin ${ }^{71}$ keffareti açıklanmaktadır. Şâri', bu yeminin edas1 ile ilgili "on yoksulu doyurmak", "onları giydirmek" ve "bir köle azat etmek"72 gibi belirli seçenekler arasında mükellefi muhayyer bırakmaktadır. ${ }^{73}$

Sonuç olarak keffaret ayetlerinde geçen "ev/ؤ lafzı mükellef için muhayyerlik bildirmektedir. Muhayyerlik ise mubahın mahiyetinde olan bir durumdur. Her ne kadar "tahyîr ibâhaya nisbetle daha kapsamlıdır; her ibâha tahyîrdir, fakat her tahyîr ibâha sayılmaz" "74 şeklinde bir genelleme yapmak mümkün olsa da bu yargı,

68 Serahsî, Usûl, 2: 213.

69 Krş. Şihabüddin Ebu'l-Abbâs Ahmed b. İdris es-Sanhâcî el-Karâfî, Şerhu tenkîhu'l-fusûl fi ihtisâri'l-Mahsûli fi'lusûl, (Beyrut: Dâru'l-fikr, 2004), 124-125; Şâtıbî, el-Muvâfakât, 1: 155-156; Ebû Zehre, Usûlüll-fikh, 33; Şaban, Usûlü'l-fikh, 243; Husarî, Nazariyyetü'l-hükm, 62; Zeydan, el-Vecîz, 31.

70 Serahsî, Usûl, 2: 213.

71 Münakid yeminin tanımı az önce yukarıda ilgili dipnotta geçmiştir.

72 el-Mâide, 5/89.

73 Şâtıbî, el-Muvâfakât, 1: 156, 3: 130; Şaban, Usûlü'l-fikh, 243.

74 Bk. Ahmet Özel, “Tahyîr”, Türkiye Diyanet Vakfi İslam Ansiklopedisi, (Ankara: TDV Yayınları, 2010), $39: 442$. 
muhayyer vacip ile mubahlık arasındaki ilişkinin varlığını ortadan kaldırmaz. Dolayısıyla mükellefin seçimli vaciplerden birini seçme hususunda muhayyer olması, bu fiillerin aslında değil, bu fiillerden birini tercih etme hususunda mubahlık (serbestlik) içerdiği anlamına gelmektedir. ${ }^{75}$

\subsection{Haramlığı Nefyeden İfadelerin Mubahlığa Delalet Etmesi}

Mubahlığı bilme yollarından biri de nassta haramlığ nefyeden ifadelerin bulunmasıdır. Nitekim haram kılmayı ve yasaklamayı nefyeden aşağıdaki ayetler mubahlığa delalet etmektedir ${ }^{76}$.

1) "De ki: "Allah’n, kulları için yarattığı zîneti ve temiz rızkı kim haram kılmış?"

De ki: "Bunlar, dünya hayatında mü’minler içindir.(Onlar için mubahtır) Kıyamet gününde ise yalnız onlara özgüdür. İște bilen bir topluluk için ayetleri ayrı ayrı açlkliyoruz." (el-A’râf, 7/32).

Ayette Allah’ın insanlar için helal/mubah kıldığı şeylerin insanlar tarafından haram kılınamayacağı ifade edilmektedir. Burada haram kılmanın nefyedilmesi/ yasaklanması bu şeylerin mubah olduğunu göstermektedir. ${ }^{77}$

2) "Ey peygamber! Eşlerinin rızasını arayarak, Allah’n sana helâl kıldığı șeyi niçin sen kendine haram ediyorsun? Allah çok bağışlayandır, çok merhamet edendir." (et-Tahrim, 66/1).

Ayette, Hz. Peygamber'in Allah’’n helal/mubah kıldığı şeyi haram kılması/ kendisine yasaklaması nehyedilmektedir. Dolayısıyla bir şeyin haram kılınması yasaklandığına göre zıddı olan helallik/mubahlık sabit olmaktadır. ${ }^{78}$

3) "Allah, sizi, din konusunda sizinle savaşmamıs, sizi yurtlarınızdan da çıkarmamış kimselere iyilik etmekten, onlara âdil davranmaktan men etmez. Şüphesiz Allah, adil davrananları sever." (el-Mümtehıne, 60/8).

Ayet, gayrimüslimlerle ilişkilerle ilgili iki temel hüküm içermektedir. Birincisi gayrimüslimlere adaletli davranmak, diğeri ise gayrimüslimlerle iyi ilişkiler kurmak. Adalet İslam’ın temel bir ilkesidir ve Müslümanların herkese karşı her zaman adaletli davranması esastır. ${ }^{79}$ Ayetin konumuzla ilgili kısmı ise gayrimüslimlerle

Ayrıca bk. Dönmez, "Mubah”, 342.

75 Şihabüddin Ebu'l-Abbâs Ahmed b. İdris es-Sanhâcî el-Karâfî, el-Furûk fi Envâri'l-burûk fi envâi'l-furuk, (Beyrut: Dâru'l-kütübi'l-ilmiyye, 1998), 2: 7-8 (Fark: 47); Şihabüddin Ebu'l-Abbâs Ahmed b. İdris es-Sanhâcî elKarâfî,, Şerhu tenkîhu'l-fusûl fi ihtisâri'l-Mahsûli fi'l-usûl, (Beyrut: Dâru'l-fikr, 2004), 124-125; Cemalüddin Abdurrahim b. Hasan el-İsnevî Nihâyetü's-sü'l fi şerhi Minhaci'l-usûl (ve maahü Süllemü'l-vusûl şerhu Nihâyetü's-sû'l li’s-Şeyh Muhammed Buhayt el-Mutî'), (Alemü'l-kütüb, ty.), 1: 135; Şâtıbî, el-Muvâfakât, 1: 155-156; Ebu Zehra, Usûlü'l-fikh, 33; Hallâf, İlmü usûli'l-fikh, 123; Şaban, Usûlü'l-fikh, 243; Husarî, Nazariyyetü'l-hükm, 62; Zeydan, el-Vecîz, 31 .

76 Medkûr, Nazariyyetü'l-ibâha, 76-77.

77 Krş. Kurtubî, el-Câmi', 9: 203.

78 Ayetin sebebi nüzûlü ile ilgili rivayetler ve içerdiği hükümlerle ilgili bk. Kurtubî, el-Câmi', 21: 67-78.

79 İslam'da adaletin yeri ve önemi hakkında bk. Mustafa Çağrıcı, "Adâlet”, Türkiye Diyanet Vakfi İslam Ansiklope- 
iyi ilişkiler kurulmasının hükmüdür. Bu konuda ayette Müslümanlara karşı savaşmayan ve düşmanlık beslemeyen gayrimüslimlerle iyi ilişkiler kurulmasının yasaklanmadığı belirtilmektedir. Buna göre ayet, dolaylı bir şekilde, İslam’a ve Müslümanlara karşı düşmanlık beslemeyenlerle iyi ilişkiler kurulmasına ruhsat/ cevaz vermektedir. $\mathrm{Bu}$ da onlarla iyi ilişkiler kurmanın mubah olduğuna delalet etmektedir. ${ }^{80}$

\subsection{Bazı Ruhsat Sebeplerinin Mubahlığı Bildirmesi}

Fıkıh usulünde azimetin ${ }^{81}$ karşılığ 1 olarak kullanılan ruhsat kavramının da ibaha/mubah kılma ile yakın ilişkisi bulunmaktadır. ${ }^{82}$ Çünkü ruhsatın özünde de "mubah kılmak" vardır ve emir ve nehiy şeklinde kesin bağlayıcı olan bir hükmü, yapma veya terk etme arasında mükellefi muhayyer bırakma anlamına gelmektedir. ${ }^{83}$ Nitekim örfî lisanda ruhsat, ibaha/mubah kılma için kullanılmaktadır. Bundan dolayıdır ki bir kişiye bir fiilin yapılması hususunda ruhsat verilmesi, kişinin bu fiili işlemesine izin verilmesi ve bu fiili yapmasının mubah kılınması anlamına gelmektedir. ${ }^{84}$

Sözlükte, kolaylık/kolaylaştırmak ve bir işte zorluğun zıddını ifade eden ruhsatın fikhî bir terim olarak -özü itibariyle aynı manada toplanan- birçok tanımı yapılmıştır. ${ }^{85} \mathrm{Bu}$ tanımlara göre fikhî bir terim olarak ruhsat, "meşakkat, zaruret, ihtiyaç gibi arıî̀ bir sebebe/özre bağh olarak kullara azîmet hükmünü (aslî hükmü) terk etme imkânı vererek söz konusu arızî durumla ilgili hükmü kolaylaştırmak ve hafifletmek için mubah kılma amacı ile küllî/genel asildan istisna olarak sonradan (ikinci defa) konmuş olan geçici hüküm"s6 anlamına gelmektedir.

Aşağıdaki naslarda aslen vacip veya haram olan fiillerin ihtiyaç ve zaruret ha-

disi. İstanbul: TDV Yayınları, 1988), 1: 341-343; Hayreddin Karaman, “Adalet”, Türkiye Diyanet Vakfı İslam Ansiklopedisi. İstanbul: TDV Yayınları, 1988), 1: 343-344.

80 Ayetin ihtiva ettiği hükümlerle ilgili bk. Kurtubî, el-Câmi', 20: 407-409.

81 Sözlükte azîmet, "bir şeye kesin olarak yönelmek, niyetlenmek" anlamındadır. Fıkıh ilminde ise, "meşakkat, zaruret ve ihtiyaç gibi ârızî bir sebebe bağlı olmaksızın -namaz, oruç, zekât vs. gibi emirler ve içki, kumar, zina gibi yasaklar olmak üzere- ilk baştan konmuş olan ve normal durumlarda her bir mükellefe ayrı ayrı hitap eden aslî hüküm” demektir. (Şâtıbî, el-Muvâfakât, 1: 300, 307; Ebû Zehre, Usûlül-fikh, 51; Zeydan, el-Vecîz, 40; Atar, Fıkıh Usûlü, 130.)

82 el-Mevsûatü'l-fikhiyye, "İbâha”, I, 130. Ruhsat ile mubâh arasındaki ilişki hakkında geniş bilgi için bk. Medkûr, Nazariyyetü'l-ibâha, 372-412; Üsame el-Hamevî, “et-Tahyîr inde'l-usûliyyîn ve eseruhû fi'l-hükmi'-teklîfî (dirâse usûliyye mukârane)", Mecelletü Camiatü Dımeşk li'l-ulûmi'l-iktisâdiyye ve'l-kânûniyye 25/1 (2009): 725-732.

83 el-Mevsûatü'l-fikhiyye, "İbâha”, I, 130; Zeydan, el-Vecîz, 40.

84 Serahsî, Usûl, 1: 117; Husarî, Nazariyyetü'l-hükm, 101.

85 Bk. Gazzâlî, el-Mustasfâ, 1: 329; Amidî, el-İhkâm, 1: 175; Şâtıbî, el-Muvâfakât, 1: 301; Zeydan, el-Vecîz, 41; Zühaylî, Usûlü'l-fikh, 1: 110; Medkûr, Nazariyyetüll-ibâha, 373; İ. Kâfi Dönmez, "Ruhsat", Türkiye Diyanet Vakfı İslam Ansiklopedisi, (Ankara: TDV Yayınları, 2008), 35: 207.

86 Hallâf, Ilmü usûli'l-fikıh, 138; Zeydan, el-Vecîz, 41; Atar, Fıkıh Usûlü, 131; Dönmez, "Ruhsat", 35: 207; Medkûr, Nazariyyetü'l-ibâha, 373. Ayrıca bk. Gazzâlî, el-Mustasfâ, 1: 330; Şâtıbî, el-Muvâfakât, 1: 301. 
linde yapılmasına izin/ruhsat verilmesi bu fiillerin geçici olarak mubah olduğuna delalet etmektdir;

1) "Ey iman edenler! Allah’a karşı gelmekten sakınmanız için oruç, sizden öncekilere farz kılındığı gibi, size de farz kılındı. Oruç, sayılı günlerdedir. Sizden kim hasta, ya da yolculukta olursa, tutamadığı günler sayısınca başka günlerde tutar. Oruca gücü yetmeyenler ise bir yoksul doyumu fidye verir. Bununla birlikte, gönülden kim bir iyilik yaparsa (mesela fidyeyi fazla verirse) o kendisi için daha hayırlıdır. Eğer bilirseniz oruç tutmanız sizin için daha hayırlıdır." (el-Bakara, 2/183-184)

Ramazan orucu, ergenlik çağına ulaşmış, akıllı her Müslümana farzdır. Ancak ayette hastalık ve yolculuk sebebiyle farz olan ramazan orucunun Ramazan ayının dışında diğer günlerde kaza edilebileceğine ruhsat verilmiştir. Buna göre hasta ve yolcu olanlar, ramazan ayında oruç tutma ve tutmama arasında muhayyerdirler. Hasta ve yolculara verilen bu ruhsat, bir ibaha şeklidir. ${ }^{87}$

2) "Allah, size ancak leş, kan, domuz eti ve Allah’tan başkası adına kesileni haram kıldı. Ama kim mecbur olur da, istismar etmeksizin ve zaruret ölçüsünü aşmaksızın yemek zorunda kalırsa, ona günah (isim) yoktur. Şüphesiz, Allah çok bağışlayandır, çok merhamet edendir." (el-Bakara, 2/173)

$\mathrm{Bu}$ ayette leş, kan, domuz eti ve Allah'tan başkası adına kesilen şeyler sarih olarak haram k1lınmıştır. Ancak ayette "felâ isme aleyh/ona günah yoktur" denilerek muztar durumda olan kişinin haram kılınan bu şeyleri yemesine ruhsat/izin verilmiştir. Buna göre aslen haram olan bir şeyin yapılmasına zaruret sebebiyle izin/ruhsat verilmesi bu fiilin yapılmasının geçici olarak mubah (ruhsat ibahası) olduğuna delalet etmektedir. ${ }^{88}$ Nitekim bu ve benzeri nasların hükmü gereğince İslam hukukunda zaruret, mubah kılma sebeplerinden biri olarak kabul edilmiş ${ }^{89}$ ve bu durum, "Zaruretler memnu' olan şeyleri mubah kılar" şeklinde kaideleştirilmiştir. Dolayısıyla mutlak anlamda ruhsat ile amel etmek mubah olmakta$\boldsymbol{d}_{\boldsymbol{1}} .^{91}$ Ancak tümel açıdan bakıldığında bir diğer ifade ile ruhsata tabi olan her bir konu kendi mahiyeti ve şartları açısından değerlendirildiğinde farklı delil ve karinelerden dolayı ruhsata tabi olan meselenin farklı hükümler alması mümkündür. Bundan dolayıdır ki ruhsat hükmü ile amel etmek mubah olduğu gibi, başka

87 el-Mevsûatü'l-fikhiyye, "İbâha”, 1: 130.

88 Şâtıbî, el-Muvâfakât, 1: 310, 311, 312; Zeydan, el-Vecîz, 38.

89 İslam hukukunda zaruret hali ve hükümlere etkisi hakkında geniş bilgi için bk. Kurtubî, el-Câmi', 3: 22-48; Abdülkerim Zeydan, "İslam Hukukunda Zaruret Hali”, trc. Hayreddin Karaman, İslamın Işı̆ğında Günün Meseleleri içinde, (İstanbul: Nesil Yay., 1988), 1: 217-276; Mustafa Baktır, İslam Hukukunda Zaruret Hali, (Ankara: Akçağ Yayınları, ty.); Halit Çalış, "Zaruret”, Türkiye Diyanet Vakfı İslam Ansiklopedisi, (Ankara: TDV Yayınları, 2013), 44: 141-144.

90 Mecelle, md. 21.

91 Şâtıbî, el-Muvâfakât, I, 309; Zeydan, el-Vecîz, 42. 
bir illetten/sebepten/delilden ve karineden dolayı mendup, vâcip ve mekruh da olabilir. Mesela, murdar eti yemek (meyte/leş) zaruret halinde mubahtır. Ancak yenmediği takdirde hayati tehlike söz konusu olursa murdar eti yemek vâcip olur. ${ }^{92}$

\section{NASSIN LAFZIYLA DOLAYLI OLARAK MUBAHLIĞA DELALET ETMESI}

Lafzî istidlâl metotları/lafız eksenli ictihad yöntemleri fıkıh usulünün önemli konularından birini oluşturmaktadır. Bu bağlamda naslarda bulunan lafzî veya aklî bazı karinelerden hareketle mubahlık hükmünün çıkarılması mümkündür. Aşağıda naslarda dolaylı olarak mubahlığa delalet eden ifadeler/üsluplar üzerinde durulacaktır. ${ }^{93}$

\subsection{Emrin (Karine ile) Mubahlığa Delalet Etmesi}

Kuran'da geçen emir sîğaları vïcûb, nedb ibaha, tehdid, irşad, te'dîb, tacîz, dua ve benzeri birçok anlama delalet edecek şekilde kullanılmıştır. ${ }^{94}$ Bundan dolayıdır ki usulcüler, belirli bir hükmün kastedildiğine dair karine olmadığı zaman ${ }^{95}$ emrin medlulüne delaletinin vucup mu, nedb mi, ibaha mı yoksa tevakkuf mu olduğu konusunda ihtilaf etmişlerdir. ${ }^{96}$

Usulcülerin çoğunluğuna göre "mutlak emir" sîğası vücûba delalet eder. Ancak karine olması halinde emir sî̆gası vücûbun dışında nedb ve ibahaya da delalet edebilir. ${ }^{97}$ Nitekim “... Allah’ın rızkından yiyiniz, içiniz.” (el-Bakara, 2/ 60) ayette geçen "yiyiniz" ve "içiniz" emir sîğaları ittifakla mubahlık bildirmektedir. Çünkü yeme ve içme insanın fitratının gereği olan tabii bir durumdur. İnsanın fitratının gereği olan bir durumu yapması için ise kesin bağlayıcılık bildiren bir emrin bulunmasına gerek yoktur. Bu yüzden bu gibi ayetlerdeki emir sîğaları mubahlık bildirmektedir. $^{98}$

\subsection{Helallik Bildiren İfadelerin Mubahlığa Delalet Etmesi}

92 Şâtıbî, el-Muvâfakât, I, 310, 311, 312; Zeydan, el-Vecîz, 43; Dönmez, “Mubah”, DİA, XXX, 343.

93 Konuyla ilgili bk. Medkûr, Nazariyyetüll-ibâha, 65, 72-78; Dönmez, "Mubâh”, 30: 341.

94 Kur’an'da emir kipinin kullanıldığı anlamlar ve örnekleri için bk. Serahsî, Usûl, 1: 14; Râzî, el-Mahsûl, 2: 39-41; İsnevî, Nihâyetü's-sü'l, 2: 245-252; Rufâi, el-Emr inde’l-usûliyyîn, 104-116.

95 Kur’an'da ibâha ifade eden emir sîğalarının çeviri problemi ile ilgili bk. Zülfikar Durmuş, "Kur’an-1 Kerim’de İbâha İfade Eden Emir Siygalarının Çeviri Problemi”, İ.Ü. İlahiyat Fakültesi Dergisi 1/2, (Güz 2010): 1-21.

96 Zeydan, el-Vecîz, 231-232; Atar, Fıkıh Usûlü, 179-180; Medkûr, Nazariyyetü'l-ibâha, 72-74;

Emrin delaleti ile ilgili görüşler hakkında bk. Ebü'l-Hüseyin Muhammed b. Ali el-Basrî, Kitâbü'l-Mu’temed fî usûli'l-fikh, thk. Muhammed Hamidullah, (Dımeşk: 1964), 1: 57-82; Alauddin Abdulaziz b. Ahmed el-Buhârî, Keşfü'l-esrâr alâ Usûl-i Fahri'l-İslam el-Pezdevî, (Beyrut: Dâru'l-kitâbi'l-arabî, 1991), 1: 260-276; Râzî, el-Mahsûl, 2: 39-96; Karâfî, Şerhu tenkîhu'l-fusûl, 103-105; İsnevî, Nihâyetü’s-sü'l, 2: 245-272; İbn Hazm, el-İhkâm, 3: 2-6.

97 Serahsî, Usûl, 1: 14; Buhârî, Keşfü'l-esrâr, 1: 260-276; Râzî, el-Mahsûl, 2: 48; Karâfî, Şerhu Tenkîhu'l-usûl, 103104; İbn Hazm, el-İhkâm, 3: 2; Basrî, el-Mutemed, 1: 57. Ayrıca bk. Rufâî, el-Emr inde’l-usûliyyîn, 118; Ögüt, "Emir", 11: 120.

98 Şaban, Usûlü'l-fikh, 328. 
Mubahlık bildiren üsluplardan biri de naslarda geçen "helal" kavramıdır.99 Sözlükte "helâl" kelimesi "mubah, câiz ve serbest olmak; ruhsat vermek; helâl olmak" gibi anlamlara gelmekte ve "haram" kelimesinin karşıtı olarak kullanılmaktadır. ${ }^{100}$ Kuran-1 Kerim'de sözlük ve terim anlamında birçok yerde kullanılan ${ }^{101}$ "helâl" kelimesi bazı ayetlerde "mubah ve serbest olmak"102; "meşru/caiz kılmak"103 gibi anlamlarda kullanılmıştır.

Fıkıh literatüründe "helal" kavramı, "haram" kavramının zıddı olarak kullanılmakdır. Ancak "helal" kavramı, vâcip, mendup ve (tenzihen) mekruhu da içerisine alan geniş bir kavramdır. ${ }^{104}$ Dolayısıyla helallik bildiren ifadelerden bir şeyin mubah olduğu anlaşılsa da vacip ve mendup olma ihtimali de olduğu için bu ifadelerin mubahlığa delaleti (karine ile) dolaylı olmaktadır. ${ }^{105}$ Buna göre "helallik bildiren ifadeler yer yer sarih nitelikte olsa da sadece haramın karşıtı anlamında düşünüldüğünde mubahın yanı sıra vacip, mendup ve rnekruhu da kapsayabileceği durumlarda ibahaya delaleti sarih olmaz." ${ }^{106}$ Bu bağlamda aşağıdaki naslarda yer alan "helal" kavramının dolaylı olarak mubahlığa delalet kapsamında değerlendirilmesi mümkündür ${ }^{107}$.

1) "Bugün size temiz ve hoş şeyler helâl kilındı. Kendilerine kitap verilenlerin yiyecekleri size helâl/mubah, sizin yiyecekleriniz de onlara helâldir/mubahtır." (el-Mâide, 5/5)

2) “...İhramlı iken avlanmayı helâl saymamanız kaydıyla ${ }^{108}$, okunacak (bildirilecek) olanlardan başka hayvanlar ${ }^{109}$ size helâl/mubah kılındı...” (el-Mâide, 5/1)

3) "Allah alışverişi helal/mubah, faizi haram kıldı" (el-Bakara, 2/175)

4) “...(Savaş esiri olarak) sahip olduklarını hariç, evli kadınlar (da size) haram kılındı... Bunların dışında kalanlar ise, iffetli yaşamak ve zina etmemek şartıyla mallarınızla (mehirlerini verip) istemeniz size helâl/mubah kılındı." (el-Nisa, 4/24)

99 el-Mevsûatül-fikhiyye, "İbâha", 1: 126; Zeydan, el-Vecîz, 38.

100 İbn Manzur, "h-1-1" mad., Lisânül-Arab, 2: 974; Kürşat Demirci, "Helâl”, Türkiye Diyanet Vakfı İslam Ansiklopedisi, (Ankara: TDV Yayınları, 1998), 17: 173-174.

101 Bk. Abdülbâkî, Mucemü'l-müfehres li elfâzi'l-Kur'ani'l-Kerim, "h-1-l” mad., s. 215-216. "Helâl" kelimesinin hadislerdeki kullanımları için bk. A. J. Wensinck, "h-1-l” mad., el-Mu'cemu'l-müfehres li elfâzi'l-hadîs, Leiden 1936-1969'dan ofset bask1, (İstanbul 1986).

102 Bk. el-Bakara, 2/196, 228, 229; el-Mâide, 5/5, 88; en-Nahl, 16/116; el-Hac, 22/30; el-Ahzâb, 33/52.

103 el-Bakara, 2/275; el-A’râf, 7/157; et-Tahrîm, 66/1.

104 Medkûr, Nazariyyetü’-ibâha, 85-86; el-Mevsûatü’-fikhiyye, “İbâha”, 1: 127; el-Mevsûatül-fikhiyye, "Helal”, 18: 74; Dönmez, "Mubah", 30: 342; Koca, "Helal”, 17: 176-177.

105 Medkûr, Nazariyyetü’l-ibâha, 75, 76; Dönmez, "Mubâh”, 30: 343.

106 Dönmez, "Mubah", 30: 343.

107 Medkûr, Nazariyyetü'l-ibâha, 76 .

108 Hac ve umre için ihrama girmiş bulunanlar karada avlanamazlar, ihramlı bir kimsenin avladığı hayvanın etinden yiyemezler.

109 Ayette geçen ve hayvanlar olarak tercüme edilen "behimetü'l-en'âm” ile kastedilen deve, sığır, koyun, keçi ve bunlara dâhil edilebilecek diğer hayvanlardır. (İbn Âşûr, et-Tahrîr ve’t-Tenvîr, 6: 78.) 
5) “Oruç gecesinde kadınlarınıza yaklaşmak size helâl/mubah kılındı." ${ }^{110}$ (el-Bakara, 2/187)

\subsection{Yasaktan Sonra Gelen Emrin İbâhaya Delalet Etmesi}

Yasaktan sonra gelen emrin delaleti ile ilgili; vucûb, nedb, ibaha ve önceki hükmün geçerli olduğu şeklinde farklı görüşler ileri sürülmüştür ${ }^{111}$ :

Müteahhirîn Hanefiler ${ }^{112}$ ile bazı Malikîler ${ }^{113}$ ve Şirâzî (ö. 476/1083) ${ }^{114}$, Semânî (ö. 489/1096) ${ }^{115}$, Râzî (ö. 606/1209) ${ }^{116}$ gibi bazı Şafiilere göre ${ }^{117}$ yasaktan sonra gelenemirvucûbbildirmektedir. ${ }^{118}$

Hanefilerden İbnü'l-Hümâm ${ }^{119}$ ve bazı Hanbeliler ${ }^{120}$ ve Şâfilerden Müzenîye (ö. 264/878) göre ise nehiyden/yasaktan sonra gelen emir, yasaklığı kaldırır ve emredilen fiilin durumunu yasaktan önceki hale getirir. ${ }^{121}$ Buna göre yasaktan önce fiil vacip ise emir ile bu fiil vacip olur, yasaktan önce fiil mubah ise emir ile fiil mubaholur. ${ }^{122}$

Mutlak emrin vücûb bildirdiğini söyleyen usulcülerin çoğunluğuna göre ise yasaktan sonra gelen emir mubahlık bildirmektedir. ${ }^{123}$ Çünkü örfen efendi köle-

110 Ayetin sebeb-i nüzulü hakkında bk. Kurtubî, el-Câmi', 3: 186-187.

111 Bk. İmamü'l-Harameyn Ebu'l-Meâlî Abdullah b. Abdullah Yusuf el-Cüveynî el-Burhân fî usûli'l-fikh, thk. Abdulazim Muhammed ed-Dîb, (Katar: 1399 h.), 1: 263-265; Râzî, el-Mahsûl, 2: 96-98; Cemaleddin Ebu Amr Osman b. Ömer b. Ebi Bekr İbnü'l-Hâcib, Muhtasaru Müntehe's-sû'l/vusûl ve'l-emel fi ilmeyi'l-usûl ve'l-cedel, thk. Nezir Hammadu, (Beyrut: Dâru İbn Hazm, 2006), 1: 678-679; Karâfî, Şerhu Tenkîhu'l-fusûl, 113-114; Basrî, el-Mutemed, 1: 82-84; İbn Hazm, el-İhkâm, 3: 77-80; Ebû İshâk İbrahim b. Alî eş-Şirâzî, el-Lüma' fî̀ usûli'l-fikh, thk. Muhyiddin Dîb Mestûr, (Beyrut/Dımeşk: Dâru'l-Kelimi't-tayyıb/Daru İbn Kesîr, 1995), 4748; Buhârî, Keşü̈l-esrâr, 1: 276-280; İsnevî, Nihâyetü’s-sü'l, 2: 272-274; Zerkeşî, el-Bahru'l-muhît, 2: 378-381; Zeydan, el-Vecîz, 234; Şaban, Usûlü'l-fikh, 333-335; Zühaylî, Usûlül-fikh, 1: 222-224; Atar, Fikıh Usûlü, 181; Medkûr, Nazariyyetü'l-ibâha, 73-74; Muhammed Edib Salih. Tefsîrü’n-nusûs fi'l-fikhi'l-İslamî. Beyrut: el-Mektebül-İslamî, 1993, 2: 360-376.

112 Örneğin Pezdevîye (ö. 482/1089) göre yasaktan sonra gelen emir vucûp ifade etmektedir. Bk. Buhârî, Keşfü'l-esrâr. 1: 276-277.

113 Karâfî, Şerhu Tenkîhu'l-fusûl, 113.

114 Şirâzî, el-Lüma', 48.

115 Sem'ânî, Kavâtıu'l-edille, 1: 108.

116 Râzî, el-Mahsûl, 2: 96.

117 Zerkeşî, el-Bahru'l-muhît, 2: 378.

118 Rufâî, el-Emr inde’l-usûliyyîn, 187-190; Edib Salih, Tefsîrü’n-nusûs 2: 364-368; Öğüt, "Emir”, 11: 120.

119 İbnü'l-hümâm, et-Tahrîr, 140-141.

120 Zerkeşî (ö. 794/1392), muhakkik Hanbelilerin bu görüşü tercih ettiğini belirtmektedir. (Zerkeşî, el-Bahru'lmuhît, 2: 381.) Ancak Ebu Ya’la el-Ferrâ (ö. (ö.458/1066) (el-Udde, 1:256) ve İbn Kudâme (ö. 620/1223) (Ravdatün-nâzır, 103-104) gibi muhakkik Hanbeli fakihler, yasaktan sonra gelen emrin ibahaya delalet ettiğini söylemektedirler.

121 Zerkeşî, el-Bahru'l-muhît, 2: 380-381.

122 Atar, Fıkıh Usûlü, 181.

123 Cüveynî, el-Burhân, 1: 263; Şirâzî, el-Lüma', 48; Râzî, el-Mahsûl, 2: 97; Serahsî, Usûl, 1: 19; Buhârî, Keșfü’-esrâr, 1: 277; İbnü'l-Hâcib, Muhtasaru Müntehe's-süll, 1: 678; Karâfî, Şerhu Tenkîhu'l-fusûl, 113; İbn Hazm, el-İhkâm, 3: 77; İsnevî, Nihâyetü's-sü'l, 2: 272-273; Zerkeşî, el-Bahru'l-muhît, 2: 378-379; Ebu Ya'la el-Ferrâ, el-Udde fî̀ usûli'l-fikh, thk. Ahmed b. Ali Seyü'l-Mübârakî, (Riyad: 1993), 1: 256; Muvaffaküddin İbn Kudâme el-Makdisî, Ravdatü’n-nâzır ve cünnetü'l-münâzır, (Riyâd: Mektebetü’meârif, 1984, 2: 75-76; Kemâlûddin Muhammed b. Abdilvâhid İbnü'l-Hümâm, et-Tahrîr fî usûli'l-fikh, Misır: Matbaatü Mustafa, 1351 h.), 140; Zeydan, el-Vecîz, 234; Atar, Fıkıh Usûlü, 181; Medkûr, Nazariyyetü'l-ibâha, 73-74; Rufâî, el-Emr inde’l-usûliyyîn, 181-186. 
sine bir şeyi yasaklasa sonra ona o şeyin yapılmasını emretse bu emir efendinin kölesine o fiili yapmasını mubah kıldığı anlamına gelir. Dolayısıyla naslardaki yasaktan sonra gelen emirler de ibaha bildirir. ${ }^{124}$ Aşağıdaki naslarda yasaktan sonra gelen emir sîğaları mubahlık bildirmektedir;

1) “Artık eşlerinizle mübâş̧erette/cinsel ilişkide bulunun ve Allah’n sizin için yazıp takdir etmiş olduğu şeyi arayın. Şafağın aydınlığı gecenin karanlığından ayırt edilinceye ( $\tan$ yeri ağarıncaya) kadar yiyin, için..." (el-Bakara, 2/187)

$\mathrm{Bu}$ ayet nazil olmadan önce orucun farz kılındığı ilk dönemlerde güneş batımından itibaren yatsıyı kıldıktan ve uyuduktan sonra imsak vaktine kadar yemek-içmek ve cinsel ilişkide bulunmak yasaklanmıştır. Bu durum ise Müslümanlara sıkıntı vermekte idi. ${ }^{125}$ Nitekim ayetin hemen öncesinde geçen "Allah, (Ramazan gecelerinde hanımlarınıza yaklaşarak) kendinize zulmetmekte olduğunuzu bildi de tövbenizi kabul edip sizi affetti." (el-Bakara, 2/187) ifadeleri de bu duruma işaret etmektedir. Bu ayette ise imsakın, yatsı namazının kılınmasından ya da uykuya dalınmasından itibaren başlamadığı, ayette ifade edilen fecr vaktine kadar yeme içmenin ve cinsel ilişkinin mubah olduğu ifade edilmektedir. Dolayıslyla yasaktan sonra gelen "mübâşerette/cinsel ilişkide bulunun", "arayın" gibi emir sîğaları, önceki yasağın kaldırıldığını bildirmekte ve hüküm ibahaya dönüşmektedir. ${ }^{126}$

2) “İhramdan çıktığınız zaman avlanınız." (el-Mâide, 5/2)

Burada "avlanınız" şeklindeki emir sîğası, karine yoluyla, ihramdan çıktıktan sonra avlanmanın mubah olduğuna delalet etmektedir. Çünkü bir önceki ayette "ihramlıyken avlanmamayı helal saymamanız kaydıyla" (el-Mâide, 5/1) denilerek ihramlıya avlanmanın yasak olduğu bildirilmiştir. Buna göre ihramdan çıkınca avlanmanın mubah olduğu anlaşılmaktadır. ${ }^{127}$

3) “...Ay hâlinde kadınlardan uzak durun. Temizleninceye kadar onlara yaklaşmayın. Temizlendikleri vakit, Allah’ın size emrettiği yerden onlara yaklaşın (hanımlarınızla cimada bulunun)..." (el-Bakara, 2/222)

Ayetteki emir sîğası ibaha bildirmektedir. Çünkü, kişinin eşi ile cinsel ilişkide bulunması aslen mubahtır. Yasaklık ise kadının ay hali olduğu süre ile sınırlıdır. Dolayısıyla kadın temizlenince yasaklık da kalkmakta ve hüküm önceki haline dönmektedir. Buna göre ayette geçici bir yasaktan sonra gelen "hanımlarınızla cimada bulunun" emri mubahlık bildirmektedir. ${ }^{128}$

124 Râzî, el-Mahsûl, 2: 97; İbn Kudâme, Ravdatün-nâzır, 104.

125 Kurtubî, el-Câmi', 3: 186-187.

126 Kurtubî, el-Câmi', 3: 192-193; Medkûr, Nazariyyetü'l-ibâha, 73-74.

127 Râzî, el-Mahsûl, 2: 97; Serahsî, Usûl, 1: 19; İbnü’l-Hâcib, Muhtasaru Müntehe’s-sü’l, 1: 678; Buhârî, Keșfü'l-esrâr, 1: 278-279; Zeydan, el-Vecîz, 234.

128 Râzî, el-Mahsûl, 2: 97; Zerkeşî, el-Bahru'l-muhît, 2: 381; İbn Kudâme, Ravdatünn-nâzır, 104. 
4) "Ey iman edenler! Cuma günü namaz için çağrı yapıldığı zaman, hemen Allah’ın zikrine koşun ve alışverişi bırakın. Eğer bilirseniz bu, sizin için daha hayırlıdır. ${ }^{129}$ Namaz kılınınca artık yeryüzüne dağılın ve Allah’ın lütfundan nasibinizi arayın" (el-Cum'a, 62/10)

Alışveriş aslen mubah olan bir fiildir. Ancak ayette cuma namazı vaktinde alışverişin geçici olarak yasak olduğu bildirilmektedir. Dolayısıyla ayette yasaklamadan sonra gelen "dağılın” ve "arayın” şeklindeki emir sîğaları cuma namazından sonra alışverişin mubah olduğuna işaret etmektedir. ${ }^{130}$

5) "Ben sizi kıtlık ve sıkıntıdan dolayı (kurban etlerini biriktirmekten) nehyetmiştim. Artık (şartlar değişti) Yiyiniz, tasadduk ediniz ve iddihar ediniz (stoklayınız/biriktiriniz)."131

Prensip olarak kurban bayramı günlerinde kesilen hayvanın etinin yenmesi, biriktirilmesi ve başkalarına ikram edilmesi câizdir/mubahtır. ${ }^{132}$ Ancak Hz. Peygamber (as), harici ve arızî bazı sebeplerden (illetten) dolayı kurban etinin biriktirilmesini geçici olarak yasaklamıştır. ${ }^{133}$ Hadiste geçen "yiyiniz", "tasadduk ediniz" ve “iddihar ediniz/biriktiniz” şeklinde yasaklamadan sonra gelen emir siğaları ibahaya delalet etmektedir. ${ }^{134}$ Çünkü daha önceden mubah olan bir konu hakkındaki yasağın kaldırılması, hükmü yasaklanmadan önceki aslî durumuna, yani mubahlığa dönüştürmektedir. ${ }^{135}$ Nitekim cumhura göre yasaklamanın illeti/sebebi ortadan kalktığı için kurban etlerinin biriktirilmesi mubahtır. ${ }^{136}$

\subsection{Vücûbdan Sonra Gelen Nehyin Mubahlığa Delalet Etmesi}

Vücuptan sonra gelen nehyin hükme delaleti konusunda ihtilaf vardır. Bu konu, "yasaktan sonra gelen emrin hükme delaleti” konusunun tam zıddını içermektedir. Bu yüzden burada da benzer görüşler ileri sürülmüştür. ${ }^{137} \mathrm{Bu}$ konuda verilen tipik örneklerden biri ise şu ayettir:

“... (Evlilik yükümlülüklerini reddederek) başkaldırdıklarını gördüğünüz kadınlara ögüt verin, onları yataklarında yalnız bırakın. (Bunlar fayda vermez de mecbur kalırsanız) onları (hafifçe) dövün. Eğer itaat ederlerse, artık onların aleyhine başka bir yol aramayın. Şüphesiz Allah, çok yücedir, çok büyüktür.” (el-Nisa, 4/34).

129 Âyetteki "çağrı" ile ezan, "Allah’ın zikri” ile de cuma namazı kastedilmektedir.

130 Serahsî, Usûl, 1: 19; Zeydan, el-Vecîz, 234; Şaban, Usûlü'l-fikh, 333-334; Medkûr, Nazariyyetü'l-ibâha, 73.

131 Konuyla ilgili farklı rivayetler için bk. Buhârî, "Edâhî”, 16; Müslim, "Edâhı̂”, 5; Muvatta, "Edâhî", 4, 6; Tirmîzî, "Edâhî", 14; İbn Mâce, "Edâhî", 16; Dârimî, "Edâhî", 6.

132 Bedruddîn Mahmud b. Ahmed Aynî, Umdetü’l-kârî şerhu Sahîhi’l-Buhârî, tsh./nşr. Abdullah Muhammed Mahmud Ömer, (Beyrut: Dâru'kütübi'l-ilmiyye, 2001), 21: 235.

133 Konuyla ilgili rivayetler ve değerlendirmeler için bk. İbn Hacer el-Askalânî, Fethu'l-Bârî bi şerhi Sahîhi'l-Buhârî, thk. Abdülkadir Şeybe el-Hamd, (Suud/Riyad: Birinci Bask1, 2001), 10: $27-32$.

134 Ferrâ, el-Udde, I, 256; İbn Kudâme, Ravdatü'n-nâzır, 104.

135 el-Mevsûatü'l-fikhiyye, “İbâha”, 1: 130; Rufâî, el-Emr inde’l-usûliyyîn, 183.

136 Konuyla ilgili görüşler için bk Aynî, Umdetü'l-kârî, 21: 236-237, 238; Askalânî, Fethu'l-Bârî, 10: $27-28$.

137 Mikdâd, Delâletü sîğatin-nehy, 93-98. 
Usulcüler, ayette geçen "öğüt verin", "yalnız bırakın” ve "(hafifçe) dövün” emirlerinden sonra gelen “... artık onların aleyhine başka bir yol aramayın” şeklindeki nehyin; tahrîme mi, kerâhaya mı yoksa ibahaya mı delalet edip etmediği konusunda ihtilaf etmişlerdir. ${ }^{138}$

Yasaktan sonra gelen emrin vücûba delalet ettiğini söyleyenler, vücuptan sonra gelen nehyin de tahrime delalet ettiğini söylemektedirler. ${ }^{139}$ Yasaktan sonra gelen emrin ibahaya delalet ettiğini söyleyenlerden bazıları vücuptan sonra gelen nehyin tahrime delalet ettiğini, bazıları ise yasaktan sonra gelen emrin ibahaya delalet etmesine kıyas ederek vücuptan sonra gelen nehyin de ibahaya delalet ettiğinisöylemektedirler. ${ }^{140}$

Vücuptan sonra gelen nehyin ibahaya delalet ettiğini söyleyenlerin gerekçesi şudur: Nehiyden önce emrin geçmesi, nehyin tahrimden ibahaya sarf edildiğinin bir karinesi olmaktadır. Nitekim emirden önce nehyin gelmesi de emrin vücûbdan ibahaya sarf edildiğinin/çevrildiğinin bir karinesi olmaktadır. ${ }^{141}$ Sonuç olarak çoğunluğa göre emirden sonra gelen nehiy tahrim veya keraheye delalet etmekle birlikte bazı usulcüler bunun ibahaya delalet ettiğini ve mükellefi muhayyer bırakma anlamı taşıyacağını ileri sürmüştür. ${ }^{142}$ Çünkü bir şeyin vacip olmasından sonra onun yasaklanması kesinlik bildiren talebin kalktığını gösterir. Böylece mezkûr fiil hakkında muhayyerlik sabit olur ve hüküm mubahlığa dönüşür. ${ }^{143}$

\subsection{Neshin Mubahlığa Delalet Etmesi}

Nesh sözlükte "iptal etmek, izale etmek, nakletmek, dönüştürmek/değiştirmek, ortadan kaldırmak" gibi anlamlara gelmektedir. ${ }^{144}$ Terim olarak ise nesh "Daha sonra gelen şer’î bir delil ile (önceki/mevcud) şer'î hükmün kaldırılması"145 olarak tanımlanmaktadır.

Nesh, bedelli ve bedelsiz olmak üzere iki şekilde olabilmektedir. ${ }^{146}$ Bizi burada ilgilendiren daha önceden vacip veya haram kılınan bir hükmün neshedilmesi ve yerine yeni bir hüküm getiren nassın bulunmamasıdır. Bir diğer ifade ile bedelsiz neshin ibahaya delalet etmesidir. ${ }^{147}$ Neshin ibahaya delalet etmesi, vacibin veya haramın bedelsiz neshinin mubahlığa delalet etmesi şeklinde iki şekilde olmaktadır: ${ }^{148}$

\footnotetext{
138 Mikdâd, Delâletü sî̆̆ati’n-nehy, 93-96.

139 Mikdâd, Delâletü sîğati’n-nehy, 94-95.

140 Mikdâd, Delâletü sîğatin-nehy, 95.

141 Mikdâd, Delâletü sîğatin-nehy, 95.

142 Şevkânî, İrşâdüll-fühûl, 193.

143 Medkûr, Nazariyyetü'l-ibâha, 74; Dönmez, "Mubâh”, 30: 343.

144 İbn Manzur, "n-s-h" mad., Lisânü'l-Arab, 6: 4407; Abdurrahman Çetin, "Nesih", Türkiye Diyanet Vakfı İslam Ansiklopedisi, (Ankara: TDV Yayınları, 2006), 32: 579.

145 Zeydan, el-Vecîz, 306; Atar, Fıkıh Usûlü, 259.

146 Medkûr, Nazariyyetü’l-ibâha, 415-417. Ayrıca bk. Buhârî, Keş̧ü̉l-esrâr, 3: 351-353.

147 Medkûr, Nazariyyetü’l-ibâha, 417. Bu konudaki tartışmalar ve farklı görüşler için bk. Medkûr, Nazariyyetü’l-ibâha, 417-420.

148 Medkûr, Nazariyyetü'l-ibâha, 75, 413-421.
} 


\section{1) Vacibin bedelsiz olarak neshedilmesinin ibahaya delalet etmesi:}

Vacip olan bir hüküm neshedildiğinde yerine gelen hükümle ilgili üç ihtimal vardır; Birincisi vacip olan hüküm neshedilerek yerine gelen hükmün nassla mubah olduğunun belirtilmesidir. İkincisi, vacip olan hüküm neshedilerek yerine gelen hükmün nassla yasak/haram olduğunun belirtilmesidir. Üçüncüsü ise vacip olan hüküm neshedilerek mubah veya haram olduğu ile ilgili bir hükmün bulunmamasidir. ${ }^{149}$

Bazı usulcülere göre vacip olan hüküm neshedildikten sonra yerine gelen hükmün haram veya mubah olduğu nassla belirtilmemiş ise bu durumda vacibin neshedilmesi ibahaya delalet etmektedir. Bu görüşü savunanlara göre vücûbun neshi fililin yapılması ve terk edilmesinde sıkıntının (harec) olmadığını gösterir. Yapılması ve terk edilmesinden dolayı sıkıntının olmadığı şer’î konum ise mubahlıktır. Buna göre vacip ile amel edilemeyeceğine göre geriye cevaz/mubahlık hükmü kalmaktadır. ${ }^{150} \mathrm{Bu}$ konuda verilen örnekler ise şu ayetlerdir:

(1) "Ey iman edenler! Peygamber ile baş başa konuşacağınız zaman, baş başa konuşmanızdan önce bir sadaka verin. Bu, sizin için daha hayırlı ve daha temizdir. Şâyet (sadaka verecek bir şey) bulamazsanız, bilin ki Allah çok bağışlayandır, çok merhamet edendir." (el-Mücadele, 58/12.)

Ayette Hz. Peygamber (as) ile baş başa konuşmadan (münâcat) önce sadaka verilmesi emredilmektedir. Ancak bu hüküm, kısa bir süre sonra bir sonraki ayet ile neshedilmiştir. ${ }^{151}$ Neshedilen bu hükmün yerine yeni bir hükmün getirilmemesi ise ibahaya delalet etmektedir. ${ }^{152}$

(2) "Sizden birinize ölüm gelip çattı̆̆ı zaman, eğer geride bir hayır (mal) bırakmısssa, anaya, babaya ve yakın akrabaya meşru bir tarzda vasiyette bulunması -Allah’a karşı gelmekten sakınanlar üzerinde bir hak olarak- size farz kılındı." (el-Bakara, 2/180)

Ayette geçen vasiyetle ilgili emir, henüz mirasla ilgili hükümler açılanmadan önce gelmiştir. Amaç ise varislerin ve akrabaların ölen kişinin geride bırakmış olduğu malındaki (miras) haklarını korumaktır. Ancak bu ayette emredilen vasiyet hükmü (cumhura göre) daha sonra gelen Nisâ sûresindeki miras ayetle$\operatorname{rinin}^{153}$ işareti ve "vârise vasiyet yoktur"154 hadisi ile neshedilmiştir. ${ }^{155}$ Vasiyetin

149 Ensârî, Fevâtihu'r-rahamût, 1: 83.

150 Râzî, el-Mahsûl, 2: 203, 206-207; Zerkeşî, el-Bahru'l-muhît, 1: 235; Medkûr, Nazariyyetü'l-ibâha, 75.

151 Elmalıll, Hak Dini, 7: 4797-4799.

152 Medkûr, Nazariyyetü'l-ibâha, 421 .

153 Miras ayetleri için bk. el-Nisa, 4/10, 11, 176.

154 Ebû Dâvûd, "Vesâyâ", 6; Tirmîzî, "Vesâyâ", 5; Nesâî, "Vesâyâ", 5; İbn Mâce, "Vesâyâ", 6. Buharî, bab başlığı yapmiş, hadisi tahrîc etmemiştir. (Buhârî, "Vesâya", 6.)

155 Elmalılı, Hak Dini, 1: 613-614. Akrabaya vasiyetin neshedilmesi ile ilgili görüşler için bk. Elmalılı, Hak Dini, 1: 613-620. 
vacip olduğunu bildiren hükmün bedelsiz olarak neshedilmesi ise bazı usulcülere göre vasiyetin serbest bırakıldığına (mubah), bazılarına göre müstehap olduğuna işaretetmektedir. ${ }^{156}$

\section{2) Haramın bedelsiz olarak neshedilmesinin ibahaya delalet etmesi:}

Neshedilen yasağın yerine vasfı belirli herhangi bir hüküm getirilmemiş ise bu durum yasaklamadan sonra gelen neshin mubahlık ifade ettiğini göstermektedir. ${ }^{157}$ Usulcüler bu konuyla ilgili yukarıda geçen Ramazan ayı gecesinde uykudan sonra da olsa imsak vaktine kadar cimanın ve yeme-içmenin yasaklanmasının kaldırılmasi ${ }^{158}$ ile üç günden fazla kurban etlerinin biriktirilmesinin yasaklanmasının kaldırılmasını ${ }^{159}$ örnek olarak vermektedirler. ${ }^{160}$ Buna göre önceden Ramazan ayında geceleri imsak vaktine kadar yasak olan yeme-içme ve cima ile kurban etlerinin üç günden fazla biriktirilmesinin yasaklanması, bu yasakların kaldırılması ilemubahllğa dönüşmüştür. ${ }^{161}$

\subsection{Haram Kılınan Şeylerden Yapılan İstisnaların Mubahlığa Delalet Etmesi}

Haram kılınan şeylerden yapılan istisna iki şekilde olabilmektedir. Birincisi sarih/açık olarak haram kılmadan yapılan istisnanın mubahlığa delalet etmesidir. İkincisi ise zımnî/üstü kapalı olarak haram kılınan şeylerden yapılan istisnanın mubahlığa delaletetmesidir. ${ }^{162}$

\section{1) Sarahaten haram kılmadan yapılan istisnanın mubahlığa delalet etmesi;}

Aşağıdaki ayette haram kılınan şeylerin tek tek sayıldığı belirtilerek şöyle denilmektedir:

"Allah, yemek zorunda kaldıklarınız dışında size neleri haram kıldığını tek tek açıklamışken, üzerine Allahın adının anıldığı hayvanları yememenizin sebebi nedir."(el-Enam,6/119) ${ }^{163}$

Haram kılınan şeyler ise şu ayette belirtilmiştir:

"Ölmüş hayvan, kan, domuz eti, Allah’tan başkası adına boğazlanan, (henüz canı çıkmamış iken) kestikleriniz hariç; boğulmuş, darbe sonucu ölmüş, yüksekten düşerek ölmüş, boynuzlanarak ölmüş ve yırtıcı hayvan tarafından parçalanmış hay-

156 Medkûr, Nazariyyetü’l-ibâha, 75; Dönmez, “Mubâh”, 30: 343.

157 Medkûr, Nazariyyetü'l-ibâha, 420-421.

158 el-Bakara, 2/187.

159 Konuyla ilgili farklı rivayetler için bk. Buhârî, “Edâhî”, 16; Müslim, “Edâhî”, 5; Muvatta, "Edâhî”, 4, 6; Tirmîzî, "Edâhî", 14; İbn Mâce, "Edâhî”, 16; Dârimî, "Edâhî”, 6.

160 Bk. Buhârî, Keșüll-esrâr, 3: 351.

161 Medkûr, Nazariyyetü'l-ibâha, 420.

162 Medkûr, Nazariyyetü'l-ibâha, 77; Dönmez, “Mubâh”, 30: 343.

163 Yenmesi haram kılınan şeyler için bakınız: el-Bakara, 2/173; el-Mâide, 5/3; el-Enâm, 7/145; en-Nahl,16/114-115. 
vanlar ile dikili taşlar üzerinde boğazlanan hayvanlar, bir de fal oklarıyla kısmet aramanız size haram kılındı." (el-Mâide, 5/3)

Yukarıdaki ayette sarih olarak sayılanların dışında kalan şeylerin mubah kılındığıanlaşılmaktadır. ${ }^{164}$

\section{2) Zımnen haram kılmadan yapılan istisnanın mubahlığa delalet etmesi;}

Hz. Peygamber (as) buyurmuşlardır:

"Üç şey dışında Müslüman kişinin kanı helal olmaz: Bunlar: zina eden evli, nefse karşı nefis, dinini terk edip İslam toplumundan ayrılan kimsedir.” ${ }^{165}$

İslam'da haklı bir sebep olmaksızın bir başkasının hayatına kastetmek haramdır. ${ }^{166}$ Yukarıdaki rivayette de zımnen/dolaylı olarak haksız ve sebepsiz yere bir kişinin canına kastetmenin haram olduğu belirtilmiştir. Ancak üç durumda bunun istisnasının olduğu, yani üç sebepten dolayı kişinin canına kastetmenin mubah olduğubelirtilmiştir. ${ }^{167}$

\section{SONUÇ}

İslam hüküm teorisinde beş temel teklîfî hükümden biri olan mubah, mükellefin yapma ve terk etme arasında muhayyer bırakıldığı en geniş hukuki serbest alanları oluşturmaktadır. İslam hüküm teorisinde nasların mubahlığa delalet etmesi ise "doğrudan" ve "dolaylı (karine ile)" olmak üzere iki şekilde olmaktadır. Nasların doğrudan mubahlığa delalet etmesi; (1) nassın sarahaten mubahlığa delalet etmesi, (2) nassın günah ve sıkıntıyı nefyederek mubahlığa delalet etmesi, (3) nassın teshîr (musahar kılma) ve imtinân (iyilikte bulunma) yoluyla mubahlığa delalet etmesi, (4) nastaki muhayyerlik bildiren bazı harflerin mubahlığa delalet etmesi, (5) haramlığı nefyeden ifadelerin mubahlığa delalet etmesi ve (6) bazı ruhsat sebeplerinin mubahlığı bildirmesi olmak üzere altı farklı şekilde olabilmektedir. Usulcüler arasında nasların doğrudan mubahlığa delalet etmesi ile ilgili önemli bir görüş ayrılı̆̆ı yoktur.

Nasların dolaylı olarak (karine ile) mubahlığa delalet ettiği yollar ise şunlardır; (1) emrin karine ile mubahlığa delalet etmesi, (2) helallik bildiren ifadelerin mubahlığa delalet etmesi, (3) yasaktan sonra gelen emrin ibâhaya delalet etmesi, (4) vücuptan sonra gelen nehyin mubahlığa delalet etmesi, (5) neshin mubahlığa delalet etmesi ve (6) haram kılınan şeylerden yapılan istisnaların mubahlığa delalet etmesi olmak üzere yine altı farklı şekilde olabilmektedir.

Usulcüler nasların dolaylı olarak mubahlığa delalet ettiği yollar üzerinde ih-

164 Elmalıll, Hak Dini, 3: 1564-1566; Medkûr, Nazariyyetü’l-ibâha, 77.

165 Buhârî, "Diyet”, 6; Müslim, "Kasâme”, 25; Tirmîzî, "Hudûd”, 15.

166 el-İsra, 17/33.

167 Medkûr, Nazariyyetü'l-ibâha, 77-78. 
tilaf etmişlerdir. Üzerinde ihtilaf edilen konuların başında ise; "emrin karine ile mubahlığa delalet etmesi", "yasak ve haram kılmadan sonra gelen emrin ibâhaya delalet etmesi", "vücuptan sonra gelen nehyin mubahlığa delalet etmesi", "neshinin mubahlığa delalet etmesi” gibi konular gelmektedir.

İslam hüküm teorisinde nasların mubahlığa delalet etme yollarının bilinmesinin önemli bir fikhî semeresinin olmadığını söylemek mümkündür. Bununla birlikte şerî̀ hükümler içerisinde en geniş alanı oluşturan mubahllğa delalet eden yolların bilinmesinin naslardan hüküm çıkarma yöntemleri açısından önem arz ettiği söylenebilir. Bu durum özellikle "emrin karine ile mubahlığa delalet etmesi", "yasak ve haram kılmadan sonra gelen emrin ibâhaya delalet etmesi", "vücuptan sonra gelen nehyin mubahllğa delalet etmesi", "neshin mubahlığa delalet etmesi" gibi konular açısından önem arz etmektedir.

Nasların mubahlığa delalet etme yollarını yukarıda sayılan maddelerle sınırlamak doğru değildir. Nihayetinde nasların mubahlığa delalet etme yolları bir ictihad işidir. Dolayısıyla İslam hüküm teorisinde nasların mubahlığa delalet etme yollarının pek çok yolu olduğunu söylemek mümkündür. Nitekim İslam hüküm teorisinde mubahlığa delalet etme yolları esas itibariyle "nass yoluyla mubahlı̆̆ bilme yolları" ve "nass dışında mubahlığı bilme yolları" olmak üzere iki başlıkta ele alınmaktadır. Yukarıda sayılan konular nasların doğrudan veya dolaylı olarak mubahlığa delalet etme yollarıdır. Nass dışı yollarla da mubahlığın sabit olabileceği durumlar söz konusu olabilmektedir.

Diğer taraftan nasların/lafızların hükme delaletinin tespiti bir ictihad işidir ve fikıh usulünde bu konu "beyan ictihadı" olarak isimlendirilmektedir. Dolayısıyla nasların mubahlığa delalet yollarının bilinmesi, ictihad ehliyetine sahip olan veya naslardan hüküm çıkarma usul ve yöntemini bilen kişilerin yapabileceği bir uzmalık işidir. Buna göre ictihad ehliyetine sahip olmayan veya naslardan hüküm çıkarma usul ve yöntemini bilmeyen kişilerin naslardan hüküm çıkarması şer’an sıkıntılı bir konudur.

Sonuç olarak İslam hüküm teorisinde mubahlık; "şer’̂̀ ibaha" ve "aslî ibaha" olmak üzere temelde ikiye ayrılmaktadır. Naslarla prensip olarak "şer'î ibaha" kapsamına giren hükümler sabit olmaktadır. Aslî ibaha kapsamına giren hükümlerde ise esas olan emredici ve/veya yasaklayıcı bir nassın bulunmamasıdır.

\section{KAYNAKÇA}

Abdülbâkî, M. Fuâd. el-Mu'cemü'l-müfehres li elfâzi'l-Kur'âni'l-Kerîm. İstanbul: el-Mektebetü'l-İslamiyye, 1982.

Abdüllâvî, Beşir el-Mekkî. Sultatü veliyyi'l-emr fi takyîdi'l-mubâh. Beyrut: Dâru Mektebeti'l-Maârif, 2011. 
Âmidî, Ebu’l-Hasan Ali b. Muhammed Seyfeddin. el-İhkâm fî usûli’l-ahkâm. 1-4. tlk. Abdurrazzak Afifi. Riyad: Dâru’s-Samîî, 2003.

Apaydın, H. Yunus. "Nehiy". Türkiye Diyanet Vakfi İslam Ansiklopedisi. 32: 544-547. Ankara: TDV Yayınları, 2006.

Apaydın, H. Yunus. İslam Hukuk Usulü. Ankara: Bilay Yayıncılık, 2017.

Askalânî, İbn Hacer. Fethu'l-Bârî bi şerhi Sahîhi'l-Buhârî.1-13. thk. Abdülkadir Şeybe elHamd. Suud/Riyad: Birinci Baskı, 2001.

Atar, Fahrettin. Fıkıh Usûlü. İstanbul: MÜİFV Yayınları, 1996.

Attâfî, Âdil. el-Emru inde'l-usûliyyîn beyne's-sĭğati ve’l-ma’nâ. Yüksek Lisans Tezi. Câmiatü Muhammed Haydar (Külliyetü'l-âdâb ve'l-lüğât), Baskara 2012/2013.

Aynî, Bedruddîn Mahmud b. Ahmed. Umdetü’l-kârî şerhu Sahîhi'l-Buhârî. 1-25. tsh./nşr. Abdullah Muhammed Mahmud Ömer. Beyrut: Dâru'kütübi'l-ilmiyye, 2001.

Basrî, Ebü'l-Hüseyin Muhammed b. Ali. Kitâbül-Mu'temed fî usûli'l-fikh. 1-2. thk. Muhammed Hamidullah. Dimeşk: 1964.

Beyânûnî Muhammed Ebü'l-Feth. "Hüküm”. Türkiye Diyanet Vakfi İslam Ansiklopedisi. 18: 466-468. Ankara: TDV Yayınları, 1998.

Beyânûnî, Muhammed Ebü’l-Feth. el-Hükmü’t-teklîfî fişs-şerîati'l-İslamiyye. Dımaşk: Dârü'l-Kalem, 1988.

Beyzâvî, Nâsıruddin Ebû Saîd Abdullah b. Ömer. Minhâcü'l-vusûl ilâ ilmi'l-usûl. Dımeşk/ Beyrut: Müessesetü'r-risale, ty.

Boynukalın, Ertuğrul. "Yemin", Türkiye Diyanet Vakfi İslam Ansiklopedisi. 43: 416-420. Ankara: TDV Yayınları, 2013.

Buhârî, Alauddin Abdulaziz b. Ahmed. Keş̧ü'l-esrâr alâ Usûl-i Fahri'l-İslam el-Pezdevî. 1-4. Beyrut: Dâru'l-kitâbi'l-arabî, 1991.

Ca’ferî, Mustafa. el-Emru ve’n-nehyü inde’l-usûliyyîn. Hartum: Câmiatü Hartûm, Külliyetü'l-kânûn, 2009.

Cüveynî, İmamü'l-Harameyn Ebu'l-Meâlî Abdullah b. Abdullah Yusuf. el-Burhân fî̀ us $\hat{u}-$ li'l-fikh. 1-2. thk. Abdulazim Muhammed ed-Dîb. Katar: 1399 h.

Çalış, Halit. "Zaruret”, Türkiye Diyanet Vakfi İslam Ansiklopedisi. 44: 141-144. Ankara: TDV Yayınları, 2013.

Çetin, Abdurrahman. “Nesih”. Türkiye Diyanet Vakfı İslam Ansiklopedisi. 32: 579-581. Ankara: TDV Yayınları, 2006.

Çetintaş, Recep, İlk Beş Asır Fıkıh Usulü Literatüründe Teklifi Hüküm Terminolojisi, Doktora Tezi, Marmara Üniversitesi, 2014.

Debûsî, Ebî Zeyd Ubeydullah b. Umer b. Îsâ. Takvîmü'l-edille fî usûli'l-fikh. thk. Şeyh Halil Muhyiddin el-Meys. Beyrut: Dâru'l-kütübi'l-ilmiyye, 2007.

Demirci, Kürşat. "Helâl”. Türkiye Diyanet Vakfı İslam Ansiklopedisi. 17: 173-174. Ankara: TDV Yayınları, 1998.

Dilek, Uğur Bekir. “Teklîfî hüküm İfade Eden Kavramların Doğuşu, Gelişimi ve Terimleşmesi”. İslam Hukuku Araştırmaları Dergisi 18 (2011): 211-242.

Dilek, Uğur Bekir. İslam Hukuk Metodolojisinde Teklifi Hüküm Terimleri: Doğuşu-Gelişimi-Terimleşmesi. Doktora Tezi, Selçuk Üniversitesi, 2010.

Dönmez, İ. Kâfi. "Mubah". Türkiye Diyanet Vakfı İslam Ansiklopedisi. 30: 341-345. Ankara: TDV Yayınları, 2005.

Dönmez, İ. Kâfi. "Ruhsat”. Türkiye Diyanet Vakfı İslam Ansiklopedisi. 35: 207-210. Ankara: TDV Yayınları, 2008. 
Durmuş, Zülfikar. "Kur’an-1 Kerim’de İbâha İfade Eden Emir Siygalarının Çeviri Problemi”. İ.Ü. İlahiyat Fakültesi Dergisi 1/2. (Güz 2010): 1-21.

Ebû Ceyb, Sa’dî. Mevsûatü'l-icma' fi'l-fikhi'l-İslamî. 1-2. Dımeşk: Dâru'l-fikr, 1984.

Ebû Zehra, M uhammed. el-Ahvâlü'ş-şahsiyye. Kâhire: Dâru'l-fikri'i-Arabî, 1957.

Ebû Zehra, Muhammed. Usûlü'l-fikh. İstanbul: Tebliğ Yayınları, ty.

Edib Salih, Muhammed. Tefsîrün-nusûs fi'l-fikhi'l-İslamî. 1-2. Beyrut: el-Mektebü'l-İslamî, 1993.

Elmalılı, Muhammed Hamdi Yazır. Hak Dini Kurân Dili. 1-10. İstanbul: Eser Neşriyat, 1979.

el-Mevsûatü'l-fikhiyye. "Helal”. Kuveyt: Vizâratü'l-evkâf ve'ş-şuûni'l-İslamiyye. 18: 74-77. Kuveyt: 1990.

el-Mevsûatül-fikhiyye. “İbâha”. Kuveyt: Vizâratü'l-evkâf ve’ş-şuûni'l-İslamiyye. 1: 128-132. Kuveyt: 1983.

Ensârî, Ebû Ayyâş Muhammed Abdül'alî b. Nizamüddin Bahrululûm el-Leknevî. Fevâtihu'r-rahamût bi şerhi Müsellemi's-sübût, 1-2. tsh. Abdullah Mahmud Muhammed Ömer. Beyrut: Dârul'l-kütübi'l-ilmiyye, 2002.

Ferrâ, Ebu Ya'la. el-Udde fî usûli'l-fikh. 1-5. thk. Ahmed b. Ali Seyü’l-Mübârakî. Riyad: 1993.

Gazzâlî, Ebû Hâmid Muhammed. el-Müstasfâ min ilmi’l-usûl. 1-4. thk. Hamza b. Züheyr Hafiz. Medine: ty.

Hallâf, Abdülvahhab. İlmü usûli'l-fikh. İstanbul: el-Mektebetü’l-İslamiyye, 1984.

Hamevî, Üsame. "et-Tahyîr inde'l-usûliyyîn ve eseruhû fi'l-hükmi'-teklîfî (dirâse usûliyye mukârane)”. Mecelletü Camiatü Dımeşk li'l-ulûmi'l-iktisâdiyye ve’l-kânûniyye. 25/1 (2009): 725-732.

Hudarî (Bek/Bey), Muhammed b. Afîfî el-Bâcûrî. Usûlü’l-fikh. Misır: el-Mektebetü't-Ticâriyyetü'l-Kübra, 1969.

Husarî, Ahmed. Nazariyyetü'l-hükm ve mesâdirü’t-teşrî fî usûli'l-fikhi'l-İslamî. Beyrut: Dârü’l-Kitâbi'l-Arabî, 1986.

İbn Abdüsselâm, İzzeddin (İzz) Ebu Muhammed es-Sülemî. el-İmâm fî beyâni edilleti’l-ahkâm. Beyrut: Daru'l-beşâiri'l-İslamiyye, 1987.

İbn Âşûr, Muhammed Tahir. et-Tahrîr ve’t-tenvîr. 1-30. Tunus: Dâru'-Tûnisiyye, 1984.

İbn Âşûr, Muhammed Tahir. İslam Hukuk Felsefesi (Gaye Problemi)(Makâsıdü'ş-şerîati'l-İslamiyye). Trc. Vecdi Akyüz-Mehmed Erdoğan. İstanbul: İklim Yayınları, 1988.

İbn Hazm, Ebu Muhammed Ali b. Ahmed b. Saîd. el-İhkâm fî usûli’l-ahkâm. 1-8. thk. Muhammed Şakir. Beyrut: Dâru'l-âfâki'l-cedîde, ty.

İbn Kudâme, Muvaffaküddin Abdullah b. Ahmed el-Makdisî. Ravdatü’n-nâzır ve cünnetü'l-münâzır fî usuli'l-fikh alâ mezhebi Imam Ahmed b. Hanbel (Ve maahâ şerhuhâ Nüzhetü'l-hâtıri'l-âtır li Abdülkadir b. Ahmed b. Mustafa Bedrân ed-Dimeşkî. 1-2. Riyâd: Mektebetü'meârif, 1984.

İbn Manzur, Ebu'l-Fazl Cemalüddin. Lisânü'l-Arab. 1-4. Kahire: Dâru'l-meârif, 1984.

İbnü'l-Hâcib, Cemaleddin Ebu Amr Osman b. Ömer b. Ebi Bekr. Muhtasaru Müntehe's-sû'l/vusûl ve'l-emel fi ilmeyi'l-usûl ve'l-cedel. thk. Nezir Hammadu. Beyrut: Dâru İbn Hazm, 2006.

İbnü'l-Hümâm, Kemâlûddin Muhammed b. Abdilvâhid. et-Tahrîr fî usûli'-fikh. Mısır: Matbaatü Mustafa, 1351 h. 
İltaş, Davut. "Hüküm Teorisi”, İslam Hukukuna Giriş. 100-126. Ed. Apaydın, H. Yunus. Eskişehir: Anadolu Üniversitesi, 2013.

İltaş, Davut. Fıkıh Usulünde Mütekellimîn yönteminin Delâlet Anlayışı. İstanbul: İSAM Yayınları, 2011.

İsnevî, Cemalüddin Abdurrahim b. Hasanç. Nihâyetü’s-sû'l fi şerhi Minhaci'l-usûl (ve maahü Süllemü'l-vusûl şerhu Nihâyetü's-sû'l liłs-Şeyh Muhammed Buhayt el-Mutî'). 1.4. Alemü'l-kütüb ty.

Karâfî, Şihabüddin Ebu'l-Abbâs Ahmed b. İdris es-Sanhâcî, (ö. 684/1285). el-Furûk fi Envâri'l-burûk fi envâi'l-furuk. Dâru'l-kütübi'l-ilmiyye, 1998 (I-IV).

Karâfî, Şihabüddin Ebu'l-Abbâs Ahmed b. İdris es-Sanhâcî, 4/1285). Şerhu tenkîhu'l-fusûl fi ihtisâri'l-Mahsûli fi'l-usûl. Beyrut: Dâru'l-fikr, 2004.

Koca, Ferhat. "Helal". Türkiye Diyanet Vakfi İslam Ansiklopedisi 17: 176-177. Ankara: TDV Yayınlar1, 1998.

Kurtubî, Ebû Abdillah Muhammed b. Ahmed el-Ensârî. el-Câmi li ahkâmi'l-Kurân. 1-24. thk. Abdullah b. Abdulmuhsin et-Türkî. Beyrut: Müessesetü’r-risâle, 2006.

Medkûr, M. Sellâm. Mebâhisü'l-hükm inde’l-usûliyyîn. Kahire: Dâru’n-nehdati'l-arabiyye, 1959.

Medkûr, M. Sellâm. Nazariyyetü'l-ibâha inde'l-usuliyyin ve'l-fukâhâ. Kahire: Dâru'n-Nehdati'l-Arabiyye, 1984.

Mikdâd, Ziyad İbrahim Hüseyin, Delâletü sî̆gatinn-nehyi ale’l-ahkâmişs-şer’iyye. Yüksek Lisans Tezi. Câmiatü’n-necâhi'l-vatâniyye. Külliyetü'ş-şerîa, 1993.

Molla Hüsrev. Mir'âtü'l-usûl. İstanbul: Dersaâdet, 1321.

Öğ̈̈t, Salim. "Emir (Fıkıh)”, Türkiye Diyanet Vakfı İslam Ansiklopedisi. 11: 119-121. Ankara: TDV Yayınları, 1995

Özel, Ahmet. “Tahyîr”. Türkiye Diyanet Vakfı İslam Ansiklopedisi. 39: 442. Ankara: TDV Yayınları, 2010.

Pala, Ali İhsan. İslam Hukuk Metodolojisinde Emir ve Yasakların Yorumu. Ankara: Fecr Yayınları, 2009.

Râzî, Fahreddin. el-Mahsûl fi ilmi'l-usûl. 1-15. thk. Cabir Feyyyâd el-Alvânî. Beyrut: Müessesetü'r-Risâle, ty.

Rufâî, Râfi' b. Taha. el-Emr ınde’l-usûliyyîn. Dımeşk/Beyrut: Daru Mehabbe/Daru Âye, 2006.

Semânî, Ebu'l-Muzafffer Mansur b. Muhammed b. Abdulcebbar eş-Şâfiî. Kavâtıu'l-edille fî usûli'l-fikh. thk. Abdullah Hafız Ahmed el-Hakemî. Riyâd: Mektebetü't-tevbe, 1998.

Serahsî, Ebû Bekr Muhammed b. Ebî Sehl. Usûlü'l-s-Serahsî. thk. Ebu'l-vefa el-Afğanî, Beyrut: Dâru'l-Ktübi'l-ilmiyye, 1993.

Seyyid Bey, Muhammed. Fıkıh Usulü (Giriş). Yay. Haz: Hasan Karayiğit. İstanbul: Düşün Yayınları, 2010.

Şaban, Zekiyyüddin. İslam Hukuk İlminin Esasları (Usûlü'l-fıkıh). Trc. İbrahim Kâfi Dönmez. Ankara: Türkiye Diyanet Vakfı Yayınları, 2015.

Şâtıbî, Ebû İshak İbrahim b. Mûsâ. el-Muvâfakât fî usûli’şsşeriâ. 1-4. nşr./tlk. Abdullah D1raz, -Dâru'l-marife, Beyrut, 1975.

Şevkânî, Muhammed b. Ali b. Muhammed. İrşâdüll-fühûl ilâ tahkîki ilmi'l-usûl. thk. Ebu Mus'ab Muhammed Saîd el-Bedrî. Beyrût: 1992.

Şirâzî, Ebû İshâk İbrahim b. Alî. el-Lüma' fî usûli'l-fikh. thk. Muhyiddin Dîb Mestûr. Beyrut/Dımeşk: Dâru'l-Kelimi’t-tayyıb/Daru İbn Kesîr, 1995. 
Taftazânî, Sa'duddin Mes'ûd b. Ömer. Şerhu't-Telvîh ala't-Tavdîh li metni't-Tenkîh fî usulil-fikh.1-2. Birinci Baskı. Beyrut: Dâru'l-kütübi'l-ilmiyye, ty.

Wensinck, A. J. Mu'cemu’l-müfehres li elfâzı'l-hadîs. "h-l-1" md. 1-8. Ofset baskı 1986.

Zerkeşî, Ebû Abdillah Bedruddin Muhammed b. Bahadır eş-Şâfiî. el-Bahru'l-muhît fî usûli'l-fikh. nşr. Abdulkadir Abdullah el-Ânî-Ömer Süleyman el-Aşkar. Kuveyt: Vizârtü’l-evkâfi'-şuûniyye, 1992.

Zeydan, Abdülkerim. “İslam Hukukunda Zaruret Hali”. Trc. Hayreddin Karaman. İslamın Işı̆̆ında Günün Meseleleri içinde. İstanbul: Nesil Yayınları, 1988. I, 217-276.

Zeydan, Abdülkerim. el-Vecîz fî usûli’l-fikh. Beyrut: Müessesetü’r-Risâle, 2011.

Zühaylî, Vehbe. Usulü'l-fikhi'l-İslamî. Dımeşk: Dâru’l-fikr, 1986. 